\title{
LOS INICIOS DEL NOTARIADO PÚBLICO \\ EN EL REINO DE CASTILLA \\ APORTACIÓN A SU ESTUDIO
}

\author{
MARÍA DOLORES ROJAS VACA \\ Universidad de Cádiz
}

\begin{abstract}
SUMARIO
1. Introducción.- 2. Elaboración del documento: 2.1. Del scriptor al escribano público. 2.2. Proceso de expedición. 2.2.1. Rogatio de las partes / Iussio notarial. 2.2.2. Imbreviatio (la nota). 2.2.3. Ingrossatio (redacción en limpio). 2.2.4. Recognitio (revisión). 2.2.5. Validatio (validación). 2.2.6. Traditio (libramiento).- 3. Forma: 3.1. Caracteres externos. 3.2. Caracteres internos. 3.2.1. Elementos de redacción (lengua y estilo). 3.2.2. Elementos del discurso diplomático. 3.2.2.1. Cartas. 3.2.2.2. Actas.- 4. Tipología documental.
\end{abstract}

\section{INTRODUCCIÓN}

Mostrar cómo y cuándo se produce la implantación del notariado público en el reino de Castilla y mediante qué procedimiento y con qué medios se realizó el documento producido por la institución en los momentos de su inicial andadura, así como cuál es la forma que presenta es el objetivo que perseguimos con estas páginas.

A tal fin, elegimos, por razones históricas y de orden práctico, un enclave geográfico específico, Burgos, cabeza de Castilla y cámara del rey ${ }^{1}$,

\footnotetext{
${ }^{1}$ Así consta en la documentación coetánea. Cfr. E. GonZÁLEZ DíEZ, Colección diplomática del concejo de Burgos (884-1369), Burgos, 1984, doc. 41 (1273), pp. 125-127.
}

«Anuario de Estudios Medievales», 31/1 (2001) 
centro político-administrativo, socio-económico y religioso del reino durante el siglo XIII ${ }^{2}$.

Los medios utilizados para llevarlo a cabo han sido, fundamentalmente, las colecciones diplomáticas editadas sobre documentos procedentes de sus archivos eclesiásticos, en especial, el catedralicio ${ }^{3}$ y el monacal de las Huelgas $^{4}$, así como un catálogo elaborado sobre el primero de tales fondos. Además, al objeto de disponer de otros puntos de comparación, hicimos uso de las colecciones diplomáticas editadas del archivo de la antigua colegiata de Valladolid $^{6}$ y de los catedralicios de Segovia ${ }^{7}$ y Ávila ${ }^{8}$. Obligado era, asimismo, servirse de los trabajos publicados que abordaban directamente el tema, con carácter general para toda la Corona castellano-leonesa ${ }^{9}$ o local sobre ciertos territorios de la misma ${ }^{10}$.

${ }^{2}$ T.F. RUIZ, El siglo XIII y primera mitad del siglo XIV, "Burgos en la Edad Media", dir. J. VALDEÓN, Madrid, 1984, pp. 99-212.

${ }^{3}$ J.M. GaRrido Garrido, Documentación de la Catedral de Burgos (1184-1222), Burgos, 1983 [cit. = Catedral de Burgos], F.J. PEREDA LlaANERA, Documentación de la Catedral de Burgos (1254-1293), Burgos, 1984 y F.J. PEREDA LlaNERA, Documentación de la Catedral de Burgos (1294-1316), Burgos, 1984 [cit. = Catedral de Burgos].

${ }^{4}$ J.M. LIZOAÍN GARRIDO, Documentación del monasterio de Las Huelgas de Burgos (12311262), Burgos, 1985 [cit. = Huelgas].

${ }^{5}$ D. Mansilla Reoyo, Catálogo documental del Archivo Catedral de Burgos (804-1416), Madrid-Burgos, 1971 [cit. = Catálogo].

${ }^{6} \mathrm{M}$. Mañueco Villalobos y J. ZuRita Nieto, Documentos de la iglesia Colegial de Santa María la Mayor de Valladolid. Siglo XIII, (1201-1280), (1281-1300), I-II, Valladolid, 1920 [cit. = Colegial de Valladolid].

${ }^{7}$ L.M. Villar García, Documentación de la Catedral de Segovia (1115-1300), Salamanca, 1990 [cit. = Catedral de Segovia].

${ }^{8}$ A. Barrios García, Documentación medieval de la Catedral de Ávila, Salamanca, 1981 [cit. = Catedral de Avila $]$.

${ }^{\circ} \mathrm{Vid}$., para todo lo relativo a la institución, J. BONO HUERTA, "2. Implantación del notariado en el siglo XIII en los reinos hispánicos. 71 - El tránsito del scriptor al notario público en el reino de Castilla", Historia del Derecho Notarial Español, I.2, Madrid, 1982, pp. 109-119. Igualmente, del mismo autor para lo relativo a la documentación, vid. La práctica notarial del reino de Castilla en el siglo XIII. Continuidad e innovación, "Notariado público y documento privado: de los orígenes al siglo XIV", I, Valencia, 1986, pp. 481-506.

${ }^{10} \mathrm{M}$. LuCAS Álvarez, Documentos notariales y notarios en el monasterio de Osera, "Actas de las I jornadas de metodología aplicada de las ciencias históricas", V, Paleografía y archivística, Santiago de Compostela, 1975, pp. 223-240 y, asimismo, El notariado en Galicia hasta el año 1300 (Una aproximación), "Notariado público y documento privado: de los orígenes al siglo XIV", I, Valencia, 1986, pp. 331-480; M.J. SANZ FUENTES, Documento notarial y notariado en la Asturias del siglo XIII" "Notariado público y documento privado: de los orígenes al siglo XIV", I, Valencia, 1986, pp. 245-280; J.M. MARTín FUERTES, Los notarios en León durante el siglo XIII, "Notariado público y documento privado: de los orígenes al siglo XIV", 
Dado que las colecciones en cuestión incluyen documentación de muy diversas categorías han sido sometidas a una criba. Seleccionamos los documentos que, intitulados por personas, bien privadas o, bien, públicas pero actuando como las primeras ${ }^{11}$, y versando sobre un asunto de derecho privado, mencionaban al responsable de su redacción o/y, en su caso, al autor material, sin aparente vinculación directa a cancillería alguna.

En total hemos barajado en torno a dos centenares de documentos que han llegado a nosotros tanto en estado de originales, únicos o múltiples, como de copias y éstas, a su vez, aisladas, certificadas o insertas, y en cartulario ${ }^{12}$.

\section{ELABORACIÓN DEL DOCUMENTO}

\subsection{Del scriptor al escribano público}

El examen de las suscripciones de los autores materiales de los documentos o, llegado el momento, de las correspondientes a notarios públicos, de las listas de testigos e, incluso, de las intitulaciones y direcciones de aquéllos, permite seguir el proceso de transformación del scriptor, profesional libre de la escritura, en el notario público ${ }^{13}$, profesional habilitado

I, Valencia, 1986, pp. 597-613, y J.M. RUIZ ASENCIO-J.A. MARTín FuERTES, La constitución del notariado público en León, "Colección documental del Archivo de la Catedral de León (12691300)”, IX, León, 1994, pp. XIX-XXIV; R.M. BLASCO MARTínEZ, La tardía implantación del notariado público en Cantabria, "Ilustraciones cántabras", Santander, 1989, pp. 21-32 y, de la misma autora, Una aproximación a la institución notarial en Cantabria. De sus orígenes a la ley del Notariado, Santander, 1990, pp. 48-55; B. CASADO QuINTANILla, Escribanos de la ciudad de Avila durante el siglo XIII, "Ánuario de Estudios Medievales", 18 (Barcelona, 1988), pp. 133138; P. Ostos-M.L. PARDO, Los escribanos públicos de Sevilla en el siglo XIII, "Notariado público y documento privado: de los orígenes al siglo XIV", I, Valencia, 1986, pp. 513-559 y, asimismo, Documentos y notarios de Sevilla en el siglo XIII, Madrid, 1989.

${ }^{11}$ Ed. M.M. CÁRCEL ORTí, Vocabulaire Internationale de la Diplomatique, Valencia, 1996, p. 23, 8, b. [cit. = Vocabulaire].

${ }^{12}$ Agradecemos al Dr. D. Pablo Antón Solé, director del Archivo Diocesano de Cádiz a D. Manuel Ravina Martín, director del Archivo Histórico Provincial de Cádiz, y a D. Matías Vicario Santamaría, director del Archivo de la Catedral de Burgos, su colaboración facilitando el acceso a los documentos examinados.

${ }^{13}$ Recogemos la denominación de notariado público presente en Vocabulaire, p.78, 294: «el notariado público es un sistema, siempre propio de Europa meridional, en el que los documentos son redactados por una persona (lat.: notarius publicus), habilitado para darles forma y conferirles la autenticidad por la aposición de su signo manual, de su firma o de una fórmula escrita por su manus publica» 
por una autoridad o persona delegada, mediante título, para dar forma y autenticidad a los documentos que redacta ${ }^{14}$.

Este proceso trascendental, pues marca el nacimiento de una institución que por necesidad social aún está viva, se operó en los territorios de los reinos de Castilla y de León a lo largo del siglo XIII' ${ }^{15}$. Es de especial interés para la Baja Andalucía por ser el sistema documental puesto en práctica, en relación con la documentación privada, cuando estas tierras se reintegren al dominio cristiano.

Para Castilla la Vieja, tras la selección efectuada, sólo Burgos, por la abundancia y carácter seriado de la documentación editada, posibilita un seguimiento de tales fórmulas durante el Doscientos y, en consecuencia, la observación de los distintos momentos del proceso.

Así, los documentos examinados nos permiten balizar el siglo XIII en torno a tres períodos en función de los distintos tipos de redactores mencionados:

a. Período de continuidad (1200-1241).

Durante este período, en sus suscripciones, los autores materiales definen su actuación acudiendo a la voz scripsit y, excepcionalmente, fecit $^{16}$ o pinxit ${ }^{17}$. Sólo de manera eventual señalan su condición de presbiter $^{18} \mathrm{o}$ succentor ${ }^{19} \sin$ aducir oficio alguno.

${ }^{14}$ J. BONO HUERTA, Historia del Derecho, I.2, pp. 109-119.

${ }^{15}$ Ibidem.

${ }^{16}$ Así, Dominicus Petri, [J.M. Garrido Garrido, Catedral de Burgos, doc. 372 (1204)]. En 1234 era scriptor del obispo, según consta en P. OsTOS SALCEDO, Documentos y cancillería episcopal de Burgos anterior a 1300", Die Diplomatik der Bischofsurkunde vor 1250, Insbruck, 1995, p. 436.

${ }^{17}$ Dominicus [J.M. GaRrido Garrido, Catedral de Burgos, doc. 399 (1207)].

${ }^{18}$ Iohannes, [J.M. GARRIDO GARRIDO, Catedral de Burgos, doc. 465 (1214)].

${ }^{19}$ Dominicus Petri, [J.M. GARRIDO GARRIDO, Catedral de Burgos, doc. 417 (1209)]. 
Como testigos tenemos constancia de la existencia de scribas/escriua nos, eclesiásticos ${ }^{20}$ y laicos ${ }^{21}$. Mientras, en calidad de intitulantes y destinatarios, concurren al otorgamiento de determinados documentos ciertos scribas de condición clerical ${ }^{22}$.

Profesionales de la redacción de documentos ${ }^{23}$, en algunos su profesionalidad queda al descubierto simplemente con observar la labor de escrituración, continuada y frecuente, que desarrollan. Es el caso de Iohannes de Riolazedo, "scriptor laico"24, que materializa 21 documentos entre 1200 y $1207^{25}$, de Nicholaus, con 31 entre 1205 y $1213^{26}$, y de Nicholaus Martini, con 42 entre 1211 y $1220^{27}$, por citar sólo los más prolíficos. Desde 1231 toman el relevo Martinus Petri, quien escribe 15 documentos entre 1231 y $1241^{28}$, y Pascasius, con 25 entre 1236 y $1241^{29}$.

En definitiva, estamos en un período caracterizado por la permanencia de la situación precedente.

${ }^{20}$ Nicholaus, [J.M. GARRIDO GARRIDO, Catedral de Burgos, doc. 430 (1210)] y Iohannes, [J.M. GARRIDO GARRIDO, Catedral de Burgos, docs. 500 (1216) y 545 (1222)].

${ }^{21}$ Iherónimus, [J.M. GARRIDO GARRIDO, Catedral de Burgos, doc. 359 (1202)] y Dionisius, [J.M. GARRIDO GARRIDO, Catedral de Burgos, doc. 400 (1207)], este último autor material del doc. 421 (1209).

${ }^{22}$ Don Iohannes, mayordomo de la iglesia de Burgos, comprador [J.M. GARRIDO GARRIDO, Catedral de Burgos, docs. 478 (1214) y 479 (1214)] y receptor de una permuta [J.M. GARRIDO GARRIDO, Catedral de Burgos, docs. 439 (1211) y 442 (1211)]. También Dominico, canónigo, receptor en una permuta [J.M. GARRIDO GARRIDO, Catedral de Burgos, docs. 444 (1212) y 445 (1212)].

${ }^{23}$ M. LuCAS Álvarez, Documentos notariales y notarios, p. 225.

${ }^{24}$ Cfr. J. Bono Huerta, Historia del Derecho Notarial Español, I. 1, Madrid, 1979, p. 113, nota 18 .

${ }^{25}$ J.M. GARRIDO GARRIDO, Catedral de Burgos, docs. 347, 348 (1200), 359 (1201), 360, 361 (1202), 364 (1203), 370, 371 (1204), 373, 376, 377, 379 (1205), 383, 384, 387, 388, 389, 391, 392 (1206), 393 (1207) y 380 (1205-1209).

${ }^{26}$ J.M. GARRIDO GARRIDO, Catedral de Burgos, docs. 378 (1205), 395, 397, 398, 400 (1207), $409,410,411,412,413,416$ (1209), 430, 431 (1210), 435, 436, 437, 438, 439, 440, 441, 442 (1211), 443, 445, 447, 448 (1212), 449, 450, 451, 452, 453, 455 (1213).

${ }^{27}$ J.M. GARRIDO GARRIDO, Catedral de Burgos, docs. 434 (1211), 454, 456, 460, 461 (1213), $462,463,464,466,467,468,471,473,474,476,477,479,482,485(1214), 486,487$ (1215), $492,493,494,495,496,497,498,499,500$ (1216), 502, 503, 504, 506, 508, 509, 512, 513, 514 (1217), 518, 521 (1219), 523 (1220).

${ }^{28}$ J.M. LIZOAÍN GARRIDO, Huelgas, docs. 261, 265, 268 (1231), 271, 272, 273, 274 (1233), 287 (1235), 310 (1238), 316, 317, 320, 321 (1240), 326, 329 (1241), 335 (1242).

${ }^{29}$ J.M. LIZOAíN GARRIDO, Huelgas, docs. 288 (1236), 293, 295, 296, 299, 300, 303, 304, $305,306,307,308,309,311,312,313,314,315,318,323,324,325$ (1241). 
b. Período de transición (1242-1254/57/62).

Aun cuando en esta etapa prevalece la situación anterior, determinados amanuenses engrosan, de modo ocasional, su suscripción con la mención del oficio que ostentan. Así, Lucas Gonzáluez, en 1255, se dice scriptor ${ }^{30}$.

De otro lado, Martinus Petri en seis documentos de 1242, 1243, 1244 y 1246, protagonizados por una dignidad eclesiástica o seglar pero consignando un asunto de derecho privado, se autotitula escriuano del conçeio de Burgos $^{31}$. Algunos autores piensan que tras este determinativo se encuentra un escribano municipal, encargado de la escrituración concejil, que ejercería a la par dicho cargo administrativo con el de escribano profesional en lo tocante a la documentación privada ${ }^{32}$. Para otros, se trataría de meros scriptores profesionales aludiendo al lugar de ejercicio del oficio para hacer notar su profesionalidad estable y sedentaria ${ }^{33}$. En fin, no faltan quienes estiman que, sin poseer todavía fe pública, aludirían a la fuente de procedencia de su auctoritas, el concejo, y, precisamente, la vinculación al mismo les otorgaría "una credibilidad comunal que cabe considerar como un primer paso hacia la «publica fides»" 34 .

Por su parte, las listas de testigos revelan, como en el período anterior, la existencia de meros escriuanos que podrían estar organizados por barrios $^{35}$.

En suma, cualquiera que sea la significación exacta que esconda la mención de escribano del concejo, no parece que podamos hablar todavía de notariado público, tanto más cuanto, para el caso de Burgos, se trata de una mención que afecta a un único individuo y que éste sólo la utiliza de manera eventual sin que la misma se acompañe de mutaciones documentales

${ }^{30}$ J.M. LIZOAÍN GARRIDO, Huelgas, doc. 482 (1255).

${ }^{31}$ J.M. LizoAín GARRIDO, Huelgas, docs. 336 (1242), 349 (1244), 365 (1246) y 370 (1246). D. MANSILla ReOYo, Catálogo, docs. 644 (1243) y 651 (1244).

${ }^{32}$ Así lo entiende M.J. SANZ FuEnTES, Op. cit., pp. 248-249.

${ }^{33}$ Cfr. J. BONO HuerTa, Historia del Derecho, I.2, p. 110.

${ }^{34}$ Así en J.A. MARTÍN FUERTES, Los notarios en León, pp. 604-605, afirmación reiterada en J.M. RuIZ ASENCIO y J.A. MARTín FuERTES, Op. cit., p. XXI. Vid., asimismo, M. LuCAS ÁlvAREZ, Documentos notariales y notarios, pp. 225-229.

${ }^{35}$ Es el caso del testigo don Iohán, «escriuano del barrio de San Martín», Vid. J.M. LizoAín GARRIDO, Huelgas, doc. 380 (1248). 
significativas. Parece, no obstante, que apunta a un cambio de situación que se gestará y consolidará en el período que veremos a continuación.

c. Período de implantación (1255/57/63-1300).

Este período lo abrimos en 1255 con la primera mención a un notario público en Valladolid. Corresponde a Garsía Rodríguez, quien figura autorizando dos escrituras por las cuales los concejos de Cigales y Mucientes reconocen la propiedad del abad vallisoletano sobre unos terrenos concedidos a aquéllos en precario para pastore ${ }^{36}$.

La misma mención la encontramos también en Burgos, en 1258, en un individuo cinco meses antes calificado en un documento procedente del fondo de las Huelgas de escriuano del conçeio de Burgos ${ }^{37}$. Y la volvemos a encontrar en Segovia ${ }^{38}$ y Ávila ${ }^{39}$ en 1263.

Creemos que estamos ya ante auténticos notarios/escribanos públicos por cuanto tales menciones se acompañan de una novedad sobresaliente en la forma externa de los documentos, cual es la presencia del signo manual, signo cuya aposición, a mayor abundamiento, nuestros notarios anuncian en sus suscripciones en lo que creemos constituye una clara toma de conciencia del valor autenticador del mismo.

Por otro lado, las datas indicadas coinciden con los momentos de redacción y difusión de los primeros códigos alfonsinos, reguladores de la institución. El Fuero Real, redactado en 1255, fue dado a Burgos, según la mayoría de los autores, en 1256 y a Valladolid en $1265^{40}$. Incluso, el historiador del Derecho, Gonzalo Martínez Díez, sitúa en 1255, paralelamente, desde Fuero Real y Espéculo, la "primera recepción del derecho romano

${ }^{36}$ M. MAÑueco Villalobos y J. ZURITA Nieto, Colegial de Valladolid, docs. LIII (pp. 304306) y LIV (pp. 319-322). En 1268 Garsía Rodríguez figura con el título de «escriuano público del conçe de Valladolit», autorizando una permuta de inmuebles protagonizada por el abad y el cabildo de Valladolid y el despensero mayor del rey y su mujer (Ibidem, doc. LXII, pp. 366-367).

${ }^{37}$ Así, Lucas González, calificado de «notario público del conceio de Burgos», en F.J. PEREDA LLANERA, Catedral de Burgos, doc. 40 (1258. 10. 28) y de «escriuano del conceio de Burgos», en J.M. LizOAín GARRIDO, Huelgas, doc. 503 (1258. 5. 18).

${ }^{38}$ J. BONO HUERTA, Historia del Derecho, I.2, p. 113, nota 16.

${ }^{39}$ Así, Martiuannes, calificado de «escriuano público de Ávila» en A. BARRIos GarCía, Catedral de Avila, doc. 88 (1263.3.13). Cfr. B. CASADO QuinTANILla, Op. cit., p. 133.

${ }^{40}$ J. BONO HUERTA, Historia del Derecho, I. 1, p. 235-236, nota 4. 
en Castilla", apuntando el destino específicamente castellano del primero que, según cree, fue dado a Burgos y a Valladolid en $1255^{41}$, mientras que el Espéculo vendría a extender el influjo del Derecho Romano a la totalidad de los territorios de los reinos de Castilla y de León ${ }^{42}$.

En cualquier caso, desde entonces, las menciones a notarios/escribanos públicos serán casi constantes.

El problema, no obstante, se nos plantea con relación a aquellos escribanos que, desde 1257, en Burgos ${ }^{43} y$, desde 1258, en Segovia ${ }^{44}$, aponen su signo a los documentos que redactan sin mencionar título alguno 0 reseñando un título distinto al de escribano/notario público. Y ello porque observamos que el hecho de que un individuo se intitule notario público en un determinado momento no significa que este título figure de modo sistemático en su producción posterior. Además, resulta frecuente en las listas de testigos que a los notarios se les denomine, sin más, escribanos, tal vez en aras de la brevedad. Si fueran notarios públicos, algo que, por el momento, sólo en algunos casos creemos poder aseverar ${ }^{45}$-dado lo limitado de la documenta

${ }^{41}$ G. MARTÍNEZ DíEZ, Los comienzos de la recepción del Derecho Romano en España y el Fuero Real, "Diritto comune e diritto locali nella storia dell'Europa", Milán, 1980, pp. 260-262.

${ }^{42}$ Ibidem.

${ }^{43}$ Petro Iohán, sin título [Cfr. F.J. Pereda Llanera, Catedral de Burgos, doc. 32 (1257) y J.M. LIZOAín GARRIDO, Huelgas, docs. 515, 517, 518 (1260)]; Martinus Petri, «escriuano mayor del conceio» [Cfr. D. MANSILLA REOYO, Catálogo, doc. 724 (1257)], sin título [Cfr. J.M. LizoAín GARRIDO, Huelgas, docs. 505, 506 (1258)]; Domingo Pérez, sin título [Cfr. F.J. PEREDA Llanera, Catedral de Burgos, doc. 41 (1258), D. MANSIlla REOYO, Catálogo, doc. 741 (1261), J.M. LizOAín GARRIDO, Huelgas, doc. 522 (1262)], Toribios [Cfr. F.J. PEREDA LLANERA, Catedral de Burgos, doc. 43 (1259)], Álvar Abril [Ibidem, doc. 46 (1260)] y Gonzalo Royz [Ibidem, doc. 56 (1261)].

${ }^{44}$ Es el caso de Belasco Iohannes que, sin mencionar título alguno, escribe y signa una compraventa de inmueble otorgada por el prior y convento de la iglesia de Segovia en favor de un canónigo de la misma catedral [L.M. VILlar GARCía, Catedral de Segovia, doc. 165 (1258)]. Con igual nombre que el notario creado por título de Alfonso X en la carta de escribanía de las Partidas (Partida 3,18,8) podría ser la misma persona, habida cuenta de que el formulario de cancillería real de Partidas recoge ejemplos del tráfico, según consta en J. BONO HUERTA, La legislación notarial de Alfonso X el Sabio: sus características, "Anales de la Academia Matritense del Notariado", XXVII (Madrid, 1985), p. 34: "Para todo ello (i. e. diferentes fórmulas) la fuente debió ser el material documental de la misma cancillería real".

${ }^{45}$ Así, en el caso de Martinus Petri, que aparece en un documento burgalés de 1257 con el título de escriuano mayor de conceio [D. MANSILLA REOYO, Catálogo, doc. 724, p. 187, lo recoge ya con el título de "notario", pero en el documento en cuestión aparece como «escriuano mayor de conceio". Cfr. ACB., V.50, P.2, F.142] al cual, sin mencionar título alguno o, excepcionalmente, bajo el de escriuano del conceio de Burgos, habíamos visto escribiendo documentos desde 1231. Sin poder, por tanto, descartar para el mismo su condición de escribano municipal, lo que no podemos aseverar con absoluta certeza es si, además, ostentaba el título de 
ción trabajada-, habría que subrayar la imprecisión terminológica presente en la práctica, que la norma también recoge ${ }^{46}$, y ponerla en relación con las vacilaciones y titubeos propios de momentos de gestación de cambios.

Consecuentemente, la implantación del notariado público en Castilla la Vieja es equiparable, por circunstancias ${ }^{47}$ y por cronología, - salvando variantes mínimas que para nada empecen la uniformidad del conjunto- a lo constatado para otros territorios de los reinos de León y de Castilla, a saber, Galicia $^{48}$, Asturias ${ }^{49}$, León $^{50}$ y Sevilla ${ }^{51}$. Difiere, por contra, de lo observado en Cantabria donde su implantación parece que fue más tardía ${ }^{52}$.

Según sea la procedencia de la auctoritas o, dicho de otro modo, en función de la autoridad que le habilite para el desempeño del oficio, las modalidades de escribanos públicos constatadas son:

escribano público. Empero, lo constatado para igual época en Valladolid [Cfr. A. RucQuoI, Valladolid en la Edad Media. I. Génesis de un poder, Valladolid, 1987, pp. 171-172. ] y Sevilla [Cfr. P. Ostos-M.L. PARDo, Documentos y notarios de Sevilla, pp. 19-20, nota con asterisco, $\mathrm{e}$, igualmente, J.D. GONZÁLEZ ARCE, Cuadernos de ordenanzas y otros documentos sevillanos del reinado de Alfonso X, "Historia. Instituciones. Documentos", 16 (Sevilla, 1989), VII, pp. 108-109 y XII, p. 110] e, incluso, con posterioridad, en Burgos [Vid. E. GONZÁLEZ DíEZ, Colección diplomática del concejo de Burgos (884-1369), Burgos, 1984, doc. 41, pp. 125-127, en copia de 1289 aparece calificado como «escriuano público ...del conceio» si bien en el doc. copiado (1273) se califica a sí mismo como «escriuano del conçeio de Burgos», sin más. Cfr. F. ARRIBAS ARRANZ, Los escribanos públicos en Castilla durante el siglo XV, "Centenario de la Ley del Notariado, Sección primera, Estudios históricos", I, pp. 205, 261 (lám. I). También puede consultarse J. BONO HUERTA, Historia del Derecho, I.2, pp. 148-149, nota 28, y E. CORRAL GARCíA, El escribano de concejo en la Corona de Castilla (siglos XI al XVII), Burgos, 1987, pp. 4-6, 13, 16, "Documentación", pp. 89-96.] convierte en más que razonable esta suposición.

${ }^{46}$ Recordamos al respecto que en Espéculo, reflejo de la práctica vivida, se califica al notario público, de manera imprecisa (Cfr. J. BONO HUERTA, Historia del Derecho, I. 1, pp. 242-243, nota 3.) como «escribano del concejo» (Espéculo 4, 12, leyes 9, 10, 11 y 36).

${ }^{47}$ Alli donde ha sido posible su constatación por la abundancia y seriación de la documentación editada (léase Burgos).

${ }^{48}$ M. LuCAS Álvarez, Documentos notariales y notarios, pp. 223-240.

${ }^{49}$ M.J. SANZ FuenTES, Op. cit., pp. 245-280.

${ }^{50}$ Cfr. J.A. MARTín FueRTES, Los notarios en León, pp. 597-613 y, asimismo, J. M. RUIZ ASENCIO-J.A. MARTÍN FUERTES, Op. cit., pp. XIX-XXIV.

${ }^{51}$ Vid. P. OSTOS-M.L. PARDO, Los escribanos públicos de Sevilla, pp. 513-559, aunque en Sevilla, conquistada por Fernando III, no puede, por razones obvias, observarse la evolución desde comienzos del siglo XIII.

${ }^{52}$ Vid. R.M. BLASCO MARTínEZ, La tardía implantación, pp. 21-32 y, de la misma autora, Una aproximación, pp. 48-55. 
-Escribano público del concejo. Como tal consideramos al que se denomina, sin más, escribano público ${ }^{53}$ y al que añade al título en cuestión el nombre concreto del concejo donde ejerce su oficio. Los encontramos en Burgos (desde 1258) ${ }^{54}$, Valladolid (desde 1255) ${ }^{55}$, Segovia (desde 1263$)^{56}$ y Ávila (desde 1263) ${ }^{57}$.

-Escribano público de la iglesia. Con frecuencia escritura documentos en Valladolid (desde 1265) ${ }^{58}$, Segovia (desde 1272) y Ávila (desde 1296). Los vallisoletanos se denominan, sin más, de la iglesia y sólo dos manifiestan recibir la habilitación del cabildo colegial ${ }^{59}$. Mientras, los de Segovia ${ }^{60}$ y Ávila ${ }^{61}$ son escribanos públicos por autoridad del obispo.

${ }^{53}$ J. BONO Huerta, Historia del Derecho, I. 2, pp. 146-147.

${ }^{54}$ Así, Lucas González [J.M. LizoAín GARRIDo, Huelgas, doc. 514 (1260)] y [F. J. PEREDA LLANERA, Catedral de Burgos, docs. 40, 100, 101, 103, 138, 264 (1258-1291)]; Gonzalo Pérez [Ibidem, docs. 64, 135, (1263, 1276)]; Petro Iohán [Ibidem, docs. 67, 154 (1264, 1278)]; Domingo Lorent [Ibidem, doc. 86 (1267)]; Diego Pérez [Ibidem, doc. 324 (1299)]; Iohán Pérez [Ibidem, docs. 235, 277, 280, 305, 318, 338 y 345 (1289-1300)]; don Iohán [Ibidem, docs. 133, 142, 143 (1276-1277)]; Domingo Ferrández [Ibidem, doc. 233 (1289)]; Iohán Dominguez [Ibidem, docs. 238, 290 (1290-1293)]; Aparicio Martínez [Ibidem, doc. 291 (1293)]; Martín González [Ibidem, doc. 297 (1293)], Ferrán Pérez [Ibidem, doc. 316 (1296)] y Iohán Pérez [D. MANSILla REOYo, Catálogo, doc. 743 (1261)].

${ }^{55}$ Garsía Rodríguez [M. MAÑueCo VIllalobos y J. ZuRITA Nieto, Colegial de Valladolid, docs. LIII, LIV, LXII (1255-1268)]; Don Fernando [Ibidem, docs. LVII, LX (1263-1266)]; Pedro Martínez [Ibidem, doc. LXV (1273)]; Ferrán Pérez [Ibidem, doc. CII (1288)]; Diego Pérez [Ibidem, doc. CXXIX (1296)].

${ }^{56}$ Cfr. J. Bono Huerta, Historia del Derecho, I. 2., p. 113, nota 16. Asimismo, Gil Yuannes, [L.M. VIllaR GARCía, Catedral de Segovia, doc. 185 (1272)], Sancho Yuannes [Ibidem, doc. 187 (1273)], Pascual Domínguez [Ibidem, doc. 196 (1276)], Pedro García [Ibidem, doc. 197 (1277)], Pascual García [Ibidem, doc. 203 (1279)], Martín Pérez [Ibidem, doc. 204 (1279)] y Alfonso Pérez [Ibidem, doc. 227 (1291)].

${ }^{57} \mathrm{Cfr}$. B. CASAdo Quintanilla, Op. cit.

${ }^{58}$ Ferrán Martínez [M. ManÑueco Villalobos y J. ZuRITA Nieto, Colegial de Valladolid, doc. LIX (1265)], Gil Pérez [Ibidem, doc. LXI (1268)], Martín Velasco [Ibidem, docs. LXIII (1271), LXVI (1275), LXVIII (1276), LXXI (1278), LXXII (1279), LXXV (1280) y LXXVII (1281)], Iohán Domínguez [Ibidem, doc. LXXIV (1280)], Bartolomé Domínguez [Ibidem, docs. LXXIX, LXXX (1283), LXXXII (1284), XCI (1287), C (1288), CVII (1289), CXVI (1290), CXXI (1293), CXXIII (1294)], Iohán Miguel [Ibidem, doc. CXXI (1292-1293)] y Iohán Alfonso [Ibidem, docs. LXXXIII (1285) y CII (1288)].

${ }^{59}$ Martín Velasco [Ibidem, doc. LXVI (1275)] y Iohán Alfonso [Ibidem, docs. LXXXIII (1285), CII (1288)].

${ }^{60}$ Don Adam [L.M. Villar García, Catedral de Segovia, docs. 186 (1272), 228 (1292)] y Domingo Velasco [Ibidem, docs. 234 (1295), 239 (1296), 240-243 (1297)].

${ }^{61}$ Iohán Pérez [A. BARrios GARCíA, Catedral de Ávila, doc. 166 (1296)], Garci Ferrández, [Ibidem, doc. 167 (1296)] y Sancho Yuannes, [Ibidem, doc. 174 (1297)]. Cfr. B. CASADO QUINTANILlA, Op. cit. 
-Escribano [público] del rey. Figura para Ávila desde 1268, actuando, inicialmente, a través de sustituto ${ }^{62}$, y, desde $1285^{63}$, además, autorizando, en casos, personalmente. En Segovia aparece desde $1273^{64}$, si bien no autorizará documento alguno hasta $1285^{65}$. En Burgos, aunque tenemos noticia de la existencia de los mismos desde $1253^{66} \mathrm{y}$, posteriormente, en la década de los setenta ${ }^{67}$, hasta los años noventa no les veremos operar como notarios autorizantes, pues con tal título se cita a alguno previamente calificado, sin más, de escribano público del concejo o a la inversa ${ }^{68}$.

-Escribano público por $N$ [ = oficial sustituido]. Es aquél que recibe la auctoritas del oficial sustituido. Actúa como delegado o mandatario del mismo ${ }^{69}$. Figura, especialmente, en Ávila (1265) y, en menor medida, en

${ }^{62}$ Es el caso de Guiralt de Sala que actúa a través de Martiuannes [A. BARRIOS GARCíA, Catedral de Ávila, docs. 92 (1268), 97 (1272)]; de Iohán Ferrández que lo hará en 1285 mediante Domingo Royz [Ibidem, docs. 125-127 (1285)], Ferrant Martínez [Ibidem, doc. 130 (1285)] y Iohán Pérez [Ibidem, doc. 131 (1285)] y en 1286 a través de Salvador Pérez [Ibidem, docs. 132133 (1286)]; de Alfonso Royz, en 1289, a través de Martín Yuannes [Ibidem, doc. 140 (1289)]; de Esteban Pérez mediante Yuannes Esteban [Ibidem, doc. 151 (1291)] y Mateos Guillelmo [Ibidem, doc. 161 (1294)]. Cfr. B. CASADO QuinTANILlA, Op. cit.

${ }^{63}$ Johán Ferrández [A. BARRIos GARCÍA, Catedral de Ávila, docs. 123 (1285) y 139 (1289)], Ferrant Martínez [Ibidem, docs. 143 (1290), 146, 147 (1291)], Álvar Royz [Ibidem, doc. 149 (1291)] y Esteban Pérez [Ibidem, doc. 160 (1294)].

${ }^{64}$ Testificando en una compraventa otorgada por particulares figura Rodrigo Yuannes [L.M. VILlAR GARCÍA, Catedral de Segovia, doc. 187 (1273)].

${ }^{65}$ Nicolás Pérez [L.M. VIllaR GaRcía, Catedral de Segovia, doc. 207 (1285)], Pascual Domínguez [Ibidem, docs. 208 (1285) y 214 (1288)], Pedro Díaz [Ibidem, doc. 226 (1291)] y Rodrigo Díaz [Ibidem, doc. 233 (1295)].

${ }^{66}$ Como testigo figura Iohán Petriz [J.M. LizoAín GARrido, Huelgas, doc. 443 (1253)].

${ }^{67} \mathrm{Cfr}$. C. AyAla MARTínez, La monarquía y Burgos durante el reinado de Alfonso $X$ Madrid, 1984, p.16 y "Apéndice", doc. VI (1278.IX.20), pp. 49-50, por el cual Alfonso X nombra procurador de Burgos en la Corte a «Ferrán Yuannes, nuestro escribano e uestro vezino». Cfr., asimismo, D. MANSILla REOYO, Catálogo, doc. 908 (1290), p. 232, según el autor, autorizado "ante el notario Fernando Ibáñez".

${ }^{68}$ Así, Iohán Pérez que desde 1289 se venía calificando de escribano público del concejo de Burgos [F.J. PEREDA LlanERA, Catedral de Burgos, doc. 235 (1289)] pasará a calificarse en 1299 escribano público por el rey en la ciudad de Burgos [Ibidem, doc. 325 (1299)] para, en el mismo año, retomar la titulación inicial [Ibidem, doc. 338 (1299)]. Igualmente, Pero López, primero escribano público de la ciudad y obispado de Burgos [Ibidem, doc. 388 (1304)] y, luego, escribano público por nuestro señor el rey en la ciudad y obispado de Burgos [Ibidem, doc. 395 (1305)]. Inversamente, la misma realidad advertimos al respecto de Iohán González, primero notario público en la ciudad y diócesis de Burgos por la autoridad real [Ibidem, docs. 340, 343, 344 (1299)] y, después, notario público de Burgos [Ibidem, doc. 368 (1302)].

${ }^{69} \mathrm{Vid}$., sobre la figura del sustituto ad vicem, J. BONO HUERTA, Historia del Derecho, I.2, pp. 322-326. 
Valladolid (1279). Los abulenses son siempre delegados o "mandatarios" de escribanos públicos reales ${ }^{70}$, mientras los vallisoletanos omiten toda alusión al título del sustituido ${ }^{71}$.

La presencia de cada tipo no es excluyente pues, de ordinario, actúan en un mismo concejo, simultáneamente, varias clases de los mismos. Poco podemos decir de su formación, salvo lo que se deduce de los documentos que escrituran. Consignaremos, así, el apoyo en las fuentes legales, lo que denota su conocimiento o, cuando menos, su uso y, asimismo, el recurso a formularios deducido del tono reiterativo de las formas empleadas en los distintos tipos. De otro lado, cabe señalar la procedencia previa, constatada para algunos, del grupo de los simples escribanos e, incluso, de los escribanos de concejo $^{72} y$, en fin, en algún caso, cierto parentesco entre los mismos ${ }^{73}$.

\subsection{Proceso de expedición}

Paralelamente a la transformación del scriptor en el notario público, asistimos a la transformación de la carta privada en la carta pública o instrumento público con un proceso de elaboración regulado por la ley ${ }^{74}$.

${ }^{70}$ Así, Martiuannes, sustituto de Guiralt de Sala [A. BARrios García, Catedral de Avila, doc. 97 (1272)]; Domingo Royz, sustituto de Johán Ferrández [Ibidem, docs. 125, 126 (1285)]; Ferrant Martínez, sustituto de Johán Ferrández [Ibidem, doc. 130 (1285)]; Johán Pérez, sustituto de Johán Ferrández [Ibidem, doc. 131 (1285)]; Salvador Pérez, sustituto de Johán Ferrández [Ibidem, docs. 132, 133 (1286)]; Martín Yuannes, sustituto de Alfonso Royz [Ibidem, doc. 140 (1289)]; Yuannes Esteban, sustituto de Esteban Pérez [Ibidem, doc. 151 (1291)] y Mateos Guillelmo, sustituto de Esteban Pérez [Ibidem, doc. 161 (1294)].

${ }^{71}$ Como sustitutos de Marcos Pérez actúan en 1279: Sancho Ferrández, escribano del concejo [M. MAÑUECo VIllalobOS y J. ZURITA NIETO, Colegial de Valladolid, doc. LXXII (1279)] y Bartolomé Domínguez, escribano público del concejo de Valladolid [Ibidem, doc. LXXIII (1279)].

${ }^{72}$ El caso más llamativo es el del notario público burgalés Lucas González quien, en 1255, aparece como mero «scriptor» [J.M. LIZOAíN GARRIDO, Huelgas, doc. 482 (1255)], mientras, en mayo de 1258, como «escriuano del conceio de Burgos» [Ibidem, doc. 503 (1258)] y, en octubre del mismo año, como «notario público del conceio de Burgos» [F.J. PEREDA LlanERA, Catedral de Burgos, doc. 40 (1258)], título que, con la variante de «escriuano público», acompañará de modo casi sistemático a su suscripción hasta 1291 [Ibidem].

${ }^{73}$ Así, el «escriuano» burgalés don Iohán Pérez era hermano del también «escriuano» don Domingo Lloreynt [F.J. Pereda LlanERA, Catedral de Burgos, doc. 64 (1263)] y don Domingo Pérez, "escriuano», yerno de don Aparicio [Ibidem, doc. 77 (1266)]. Por su parte, Martín González, escribano público en 1293 [Ibidem, doc. 297], era hijo de Gonzalo, «el escriuano» [Ibidem, doc. 214 (1286)].

${ }^{74}$ J. BONO HUERTA, Historia del Derecho, I. 1, pp. 179-186. 
Fuero Real, Espéculo y Partidas, con carácter general, y Fuero de Soria, de carácter local, constituyen el marco legal de referencia.

En estos Códigos la práctica documental del notario público castellano queda vertebrada en torno a dos - nota y carta- (Fuero Real 1, 8, leyes 2 , $3,4,5,6^{75}$, Fuero de Soria 6, ley 73, y Partida 3, 19, 9 y 3, 18, 55 $5^{76}$ ) o tres extensiones - nota, registro y carta- (Espéculo 4, 12, $8^{77}$ ).

Rastrear sobre los documentos el camino recorrido (iter) hasta que éstos alcanzaron su perfección e, incluso, fueron entregados a la parte interesada o cumplieron, cuando resulta procedente, el requisito de la publicación será nuestro objetivo inmediato.

\subsection{1. "Rogatio" de las partes / "Iussio" notarial}

La solicitud de escrituración ${ }^{78}$, como es usual en la documentación "privada", abre el iter genético de nuestros documentos ${ }^{79}$. Cuando algo mencionan, se muestra como el ruego, petición («pedimiento») o/y mandato ${ }^{80}$ que, en presencia de los testigos, realiza el actor/es al escribano público del concejo o de la iglesia para que haga o escriba el documento, denominado «carta», «instrumento», «carta pública» o «instrumento público»:

${ }^{75}$ Vid. A. Rodríguez AdRados, La pragmática de Alcalá, entre las Partidas y la Ley del Notariado, "Homenaje a Juan Berchmans Vallet de Goytisolo", VII, Madrid, 1988, pp. 551-553.

${ }^{76}$ Ibidem, pp. 554-557.

${ }^{77}$ Triple redacción que, al comentar el Código en cuestión con relación a este punto, A. RODRÍGUEZ ADRADOS, Op. cit., pp. 553-554, califica de mera apariencia. Por contra, J. BONO HUERTA, Breve introducción a la Diplomática notarial española (Parte $1^{a}{ }^{2}$.), Sevilla, 1990, p. 40, la afirma, refiriéndose con exclusividad a Espéculo, si bien explica que "no quedó claramente impuesta por la legislación real, por lo que el registro o segunda redacción se llevó muy imperfectamente".

${ }^{78}$ Vocabulaire, p. 84, 326: "La rogatio (o rogitio) es la solicitud de instrumentación de un documento privado".

${ }^{79}$ A. PRATESI, Genesi e forme del documento medievale, Roma, 1979, p. 50.

${ }^{80} \mathrm{El}$ carácter reclamatorio que reviste, en casos, la solicitud de las partes no debe extrañar pues figura ya en los modelos incluidos en Espéculo 4, 12, 40 (adopción), 4, 12, 41 (quitamiento), $4,12,43$ (manumisión) y 4, 12, 44 (testamento). Por su parte, Partida 3, 18, 54 conjuga el tono inyuntivo y rogado, prevaleciendo este último en el modelo de compraventa presente en Partida 3, 18, 56 y, por contra, el primero en Partida 3, 19, 9. 
Et, porque esto non venga en dubda, mando fazer esta carta a Pero Martínez, escriuano público del conceio de Valladolit... ${ }^{81}$.

Et, porque esto sea firme et non venga en dubda, nos, los dichos don Matheos et donna Eluira, rogamos a Martín Velasco, público escriuano del Cabildo de la eglesia de Valleolit (sic), que nos faga de tod esto un público instrument... ${ }^{82}$.

En documentos autorizados por sustitutos a éstos se dirige, directamente, el ruego o mandato de la parte/s. Empero, a veces, el sustituto hace notar que procede previo el mandato del escribano público sustituido. Es el reflejo expreso de la iussio notarial que postcede a la solicitud de las partes en aquellos oficios donde el notario se sirve de sustitutos ${ }^{83}$ o amanuenses ${ }^{84}$ :

Yo, Martiuannes, la escrevi por mandado de don Guiralt de Sala, escrivano del rey en Ávila, e fiz este mi signo (signo) en esta carta ${ }^{85}$.

Otra manifestación, más genérica, de la iussio notarial, por cuanto omite el nombre concreto del destinatario del mandato, la encontramos en ejemplares autorizados por escribanos públicos reales, de modo mayoritario ${ }^{86}$, y, excepcionalmente, en alguno suscrito por escribano público de la iglesia ${ }^{87}$ 0 , incluso, sustituto ${ }^{88}$. Bajo la forma: «fiz escriuir» equivaldría al mandato del notario al amanuense o escribiente bajo sus órdenes para que inicie el mecanismo de la puesta por escrito ${ }^{89}$ :

${ }^{81}$ M. MaÑueco Villalobos y J. Zurita Nieto, Colegial de Valladolid, doc. LXV (1275).

${ }^{82}$ Ibidem, doc. LXVI (1275).

${ }^{83}$ A. BARrios García, Catedral de Ávila, docs. 90 (1265), 92 (1268).

${ }^{84}$ L.M. Villar García, Catedral de Segovia, doc. 104 (1278).

${ }^{85}$ A. Barrios García, Catedral de Ávila, doc. 92 (1268).

${ }^{86}$ Constituye excepción, A. BARrios GARCÍA, Catedral de Ávila, doc. 143 (1290).

${ }^{87}$ L.M. VILlar García, Catedral de Segovia, doc. 239 (1296).

${ }^{88}$ A. Barrios García, Catedral de Ávila, doc. 133 (1286).

${ }^{89}$ Vid. L.M. Villar García, Catedral de Segovia, docs. 207, 208 (1285), 214 (1288), 226 (1291), 233 (1295), 239 (1296) y A. BARRIOS GARCíA, Catedral de Ávila, docs. 123 (1285), 139 (1289), 160 (1294). 
Yo, Nicolás, escrivano público a la merçed del rey en Segovia, la fiz escrivir et fiz ý este mi signo en testimonio ${ }^{90}$.

La información correspondiente consta bien en el anuncio de validación, formulado por el actor(es), bien en la suscripción del escribano público autorizante $o$, incluso, en la fórmula que introduce la lista de testigos:

Testigos que fueron presentes, llamados e rogados, quando $\mathrm{N}$ y $\mathrm{N}(i . e$. donantes)... mandaron fazer esta carta... ${ }^{1}$.

Solicitada la escrituración es cuando procede la puesta por escrito. Ésta se podrá desarrollar mediante dos o tres extensiones: nota y carta, de un lado, o nota, registro y carta, de otro.

\subsection{2. "Imbreviatio" (la nota)}

Distinta del borrador ${ }^{92}$, por cuanto ya no se trata de un apunte informal destinado a facilitar la extensión del documento definitivo, es la nota, primera "fase textual" o primera redacción del documento notaria ${ }^{93}$. Minuta, si empleamos la terminología diplomática tradicional ${ }^{94}$, constituye, como señala Alessandro Pratesi, el segundo momento en el proceso formativo del "documento privado" 95 , siendo un texto más o menos abreviado que contiene lo esencial del negocio y al cual se habrá de acomodar el documento definitivo ${ }^{96}$. De la realización de la nota, exigida por la legislación, según se ha dicho, nada sabemos para Castilla la Vieja. No hemos encontrado mención expresa alguna.

No obstante, la práctica seguida en otros territorios de los reinos de León y de Castilla suple tal omisión. Antes de la aparición de las fuentes

${ }^{90}$ L.M. Villar García, Catedral de Segovia, doc. 207 (1285).

${ }^{91}$ M. MAÑUeCo Villalobos y J. Zurita Nieto, Colegial de Valladolid, doc. XCI (1287).

${ }^{92}$ Vocabulaire, p. 88, 349.

${ }^{93} \mathrm{Vid}$. J. BONO HUERTA, Breve introducción, pp. 31-38.

${ }^{94}$ Vocabulaire, pp. 88-89, 353 y 357. Vid., igualmente, O. GUYOTJEANNIN, J.PYCKE, B.-M Tock, Diplomatique médiévale, París, 1993, pp. 242-243.

${ }^{95}$ A. PRATESI, Op. cit., pp. 51-52.

${ }^{96} \mathrm{~J}$. BONO HUERTA, Breve introducción, pp. 32-38. 
legales que imponen su redacción, ya en 1245 las documenta, para Galicia, Manuel Lucas Álvarez ${ }^{97}$. Después de la redacción de Fuero Real (1255) las evidencias se multiplican no sólo para Galicia ${ }^{98}$ sino también para Sevilla ${ }^{99}$ y León ${ }^{100}$.

De la composición de la nota nos informan testimonios tardíos. Uno es la copia certificada de una "carta de población" $(1302)^{101}$. La extiende un escribano público de Sevilla en 1312, previo mandato del alcalde del lugar, a instancia del cabildo eclesiástico sevillano por deterioro del original ${ }^{102}$.

Otro es la exemplatio de una escritura de compraventa de 1319 perdida, extendida en 1321, previo mandato del juez y a partir de la nota de la misma, por el propio notario que redactó esta última ${ }^{103}$.

Se desprende de tales ejemplos, además de la efectiva redacción de la nota, la composición variable de la misma: redactada en forma objetiva y breve, una, subjetiva y extensa, otra. Estos ejemplos no hacen sino corroborar la variedad compositiva que acusan las notas asentadas en los libros de notas medievales conocidos, actualmente, para Castilla ${ }^{104}$.

En cualquier caso, una vez leída la nota ante las partes y los testigos y prestada por aquéllas su conformidad (otorgamiento), los notarios debían conservarlas con el fin de que «si la carta se perdiere, o viniere sobre ella alguna dubda, que pueda ser probado por la nota donde fue sacada ${ }^{105}$. Parece

${ }^{97}$ M. LuCAS Álvarez, Documentos notariales y notarios, p. 230: «Ego, I. Didaci, notarius Pontisveteris, iuratus, conf., et de notula mea infrascriptus Ranimirus Pelagii notarius nominati concilii».

${ }^{98}$ Ibidem, pp. 230-231 y, del mismo autor, "El notariado en Galicia", pp. 364-365, notas 92 , 93 y 94

${ }^{99}$ En Sevilla la primera mención a la nota data de 1279 , generalizándose las menciones a la misma desde 1290, según consta en P. OstOS-M.L. PARDO, Documentos y notarios de Sevilla, pp. 39-40.

${ }^{100}$ R.M. BLASCO MARTíNEZ, La tardía implantación, p. 29, nota 54.

${ }^{101} \mathrm{P}$. Ostos SALCEDO, Una renovación documental sevillana (S. XIV), "Historia. Instituciones. Documentos", 19 (Sevilla, 1992), pp. 307-316.

${ }^{102}$ Ibidem.

${ }^{103}$ Vid. A. Vilaplana, La Colección Diplomática de Santa Clara de Moguer. 1280-1483, Sevilla, 1975, docs. $\mathrm{n}^{\mathrm{0}} .8$, pp. 112-113, y 11, pp. 116-117.

${ }^{104}$ Cfr. M.D. RoJAS VACA, Un registro notarial de Jerez de la Frontera (Lope Martínez, 1392), Madrid, 1998, en cuyo prólogo (pp. 13-15) J. BONO HUERTA ofrece relación actualizada de los más antiguos publicados, tanto de la Corona de Castilla como de la de Aragón.

${ }^{105}$ Fuero Real 1, 8, 2. 
que, inicialmente, tales notas se extendían en hojas separadas de pergamino ${ }^{106}$, pero Espéculo y Partidas establecieron su asiento en un «libro por registro» ${ }^{107}$, norma de aplicación general desde fines del reinado de Alfonso $\mathrm{X}^{108}$. Es lo que, técnicamente, se conoce con el nombre de libro de notas ${ }^{109}$ aunque puede y debe, -conforme a la terminología empleada en los documentos y en las Partidas-, denominársele registro ${ }^{110}$.

Disponemos, para Ávila, de una mención en el tenor a la registración $\mathrm{y}$, para Burgos, de otra al registro.

La primera, sita en el anuncio de validación que el notario pone en boca del actor, expresa el ruego de éste para que el escribano público proceda a registrar la compraventa otorgada. Al respecto, sorprende el carácter rogado con el cual el actor solicita del notario tal actuación cuando es un hecho que a la misma se la tenía como una obligación:

E, porque esto sea firme e non venga en dubda, ruego a vos, Johán Pérez $(i$.

e. escribano público), que la registedes (sic)..." .

Un ejemplar burgalés, datado en 1289, refiere, en la suscripción notarial, la extensión de una «carta» de compraventa por el escribano público de Burgos que la autoriza, Domingo Fernández, partiendo del «registro» del escribano Pero Martínez:

${ }^{106} \mathrm{Cfr}$. J. BONo HuERTA, Modos textuales de transmisión del documento notarial medieval, "Estudis històrics i documents dels Arxius de Protocols", XIII (Barcelona, 1995), pp. 80-82. Vid., asimismo, M.T. CARRASCO LAZARENO, "Notae in cartulis» en la documentación madrileña del siglo XIII (contribución al estudio de la elaboración del documento privado en Castilla), "Espacio, Tiempo y Forma", Serie III, Ha . Medieval, 10 (Madrid, 1997), pp. 31-45.

${ }^{107} \mathrm{~J}$. BONO HUERTA, Breve introducción, p. 34. Por su parte, A. Rodríguez AdRADOS, Op. cit., p. 553, estima, por contra, apoyándose en Fuero Real 1, 8, 4, que ya este Código exigía la conservación de la nota en un libro: "e quando el escribano público moriere, los alcaldes recauden luego las notas del registro de todas las cartas que aquel escribano fizo e dévenlo dar al otro escribano que viniere en su lugar, por mandado del rey"; las notas se coleccionan, pues, en un "registro", y es éste, como unidad ("dévenlo", en singular) y no las notas sueltas, lo que se entrega al escribano sucesor".

${ }^{108} \mathrm{~J}$. BONO HUERTA, Modos textuales, pp. 82-84.

${ }^{109}$ Ibidem.

${ }^{110}$ Partida 3, 19, 9.

${ }^{11}$ AHN, Sección Clero, "Ávila. Catedral. Pergaminos", carpeta 22, nº . 5. Cfr. A. BARRIOS García, Catedral de Avila, doc. 131 (1285). 
Et yo, Domingo Ferrández, (signo) escriuano público de Burgos, que escriuí esta carta del registro de Pero Martínez, escriuano, e fiz en ella mío signo ${ }^{112}$.

Nuestra primera impresión fue pensar en Martínez como mero amanuense pero, a lo que sabemos, no eran éstos quienes, de ordinario, conservaban los registros, si bien en Asturias se ha constatado la presencia de escribanos-registradores ${ }^{113}$ y en Sevilla, excepcionalmente, la nota estaba en poder de un simple escribano ${ }^{114}$. También pensamos en él como notario fallecido pero en contra de esta hipótesis jugaba la ausencia del preceptivo decreto judicial y la existencia de un escribano público de igual nombre autorizando, por las mismas fechas, documentos procedentes de los archivos monacales de Oña y Las Huelgas. Nos inclinamos a creer que el notario en cuestión estuviera temporalmente incapacitado - por enfermedad, ausencia u otra causa que se nos escapa- para ejercer el oficio, circunstancia prevista por la ley ${ }^{115}$, pues figura (caso de ser el mismo) escribiendo y signando un documento de Oña, datado en $1283^{116}$, y algunos otros de Las Huelgas, datados entre 1293 y $1297^{117}$. También se deja ver como testigo en un documento burgalés de 1293, con igual denominación de «escribano» ${ }^{18}$, término usual en la testificación aunque a los mismos les veamos autorizar ejemplares con el título de «escriuano/notario público».

Por otro lado, una compraventa abulense de 1286, escrita y signada por Salvador Pérez, sustituto del escribano del rey Johan Ferrández, recoge en el ángulo inferior derecho del pergamino, donde se extendió la grossa, la sigla $\boldsymbol{R}^{119}$, a la manera usada por los notarios asturianos, según constata María

${ }^{112}$ F.J. Pereda Llanera, Catedral de Burgos, doc. 233 (1289).

${ }^{113}$ M.J. SANZ Fuentes, Op. cit., p. 252.

${ }^{114}$ J. BONO HUERTA, La práctica notarial, p. 500, nota 75 .

${ }^{115}$ Fuero Real 1, 8, 7 :«...si acaeciere que alguno de los escriuanos enfermare o por otra razón non pudiere fazer la carta quel mandaren, uayan a alguno de los otros escriuanos públicos que la faga».

${ }^{116}$ I. OCEJA GONZALO, Documentación del monasterio de San Salvador de Oña (1032-1284), Burgos, 1983, doc. 248 (1283).

${ }^{117}$ A. CASTRO GaRRIDO y J.M. LizOAÍN GARRIDO, Documentación del monasterio de Las Huelgas (1284-1306), Burgos, 1987, docs. 90 (1293), 94 (1294), 96 (1294), 97 (1294), 106 (1295), 116 (1296) y 117 (1297).

${ }^{118}$ F.J. PEREDA LlanERA, Catedral de Burgos, doc. 297 (1293).

${ }^{119}$ AHN, Sección Clero, "Ávila. Catedral. Pergaminos", Carpeta 22, nº. 6. Vid. fig. 1. 
Josefa Sanz Fuentes, muy probablemente para indicar su registro ${ }^{120}$. Esta anotación, esporádica, se torna sistemática en los documentos autorizados por Domingo Domínguez, también notario de Ávila, durante $1301^{121}$.

De cualquier modo, tales menciones, bien en el tenor bien fuera del mismo, se vienen a sumar a otras tantas que ora referidas, con exclusividad y de modo expreso, a la nota, ora al registro o a ambos, ponen de manifiesto que la formación de las notas, de un lado, y su conservación (en hojas, en cuadernos o en libros), de otro, eran una realidad en Galicia, ya desde la primera mitad del siglo XIII ${ }^{122}$, y para Asturias ${ }^{123}$, Andalucía ${ }^{124}$ y los territorios de León ${ }^{125}$ y de Castilla ${ }^{126}$ en la segunda. Al mismo tiempo revelan la existencia de un notariado plenamente consolidado o, como ha señalado Rosa María Blasco Martínez, "una práctica notarial plena"127 por lo que supone de organización burocrática.

Así, aunque no se conserven libros de notas de Castilla y de León, para el siglo XIII los datos apuntados son harto expresivos. Creemos que no podrían diferir mucho de los más antiguos conservados. Recordamos al respecto que, hasta el momento, el más antiguo de los publicados procede de

${ }^{120}$ Vid. M.J. SANZ Fuentes, Op. cit., p. 253.

${ }^{121}$ AHN, Sección Clero, "Ávila. Catedral. Pergaminos", carpeta 24, $\mathrm{n}^{\mathrm{os}} .14,15,17,18$ y 20 y carpeta $25, \mathrm{n}^{\circ}$. 1. Vid. fig. 2.

${ }^{122}$ M. LuCAS Álvarez, El notariado en Galicia, p. 364.

${ }^{123}$ Cfr. M.J. SANZ Fuentes, Op. cit., pp. 252-253.

${ }^{124}$ P. Ostos-M.L. PARDo, Documentos y notarios de Sevilla, p. 40.

${ }^{125}$ Para Salamanca hemos localizado una mención, datada en 1290. Es una copia en cartulario de un mandato de Sancho IV, extendida por un notario público salmantino a partir de la nota del registro de un notario fallecido: «Et yo, Martín Domínguez, notario público del rey en Salamanca, por el poder que me mío sennor el rey dio que me mandó que signase todas las cartas que fincaron por signar que Iohán Escriván non signó en su vida et, porque fallé esta nota en el registro, fiz scrivir esta carta et pús en ella mío signo a tal», J.L. MARTín MARTín ET ALII, Documentos de los Archivos catedralicio y diocesano de Salamanca, Salamanca, 1977, doc. 423 (1290), p. 532. Prescindiendo de particularidades, esta mención es igual a otra algo anterior y de la misma zona de que se tenía noticia, R.M. BLASCO MARTínEZ, La tardía implantación, p. 29, nota 54: «Iohán Royz, notario público del rey en Benavente, fallé la nota desta carta en el registro que tenía Iohán Martínez, que tuvo las vezes de don Bartolomei, notario que fue de Benavente. Et porque Iohán Martínez no usava de la notaría et don Bartolomé non era, fiz en esta carta mío signo en testimonio de verdat», archivo monasterio Carrizo, $\mathrm{n}^{\circ} .529$.

${ }^{126} \mathrm{Vid}$. notas a pie 9 y 10 .

${ }^{127}$ R.M. BLASCO MARTíNEZ, La tardía implantación, p. 29. 
Jerez de la Frontera. Es un fragmento de un libro de notas, datado en 1392, obra del escribano público de la misma localidad Lope Martínez ${ }^{128}$.

Otra mención, de Salamanca, datada en 1285, es en extremo curiosa. Nos refiere la extensión y signado de un testamento, por mandato del alcalde del lugar, a partir del «registro de los testamentos» de otro notario, fallecido:

\begin{abstract}
Et yo, Apariçio, et yo, Alfonso Yannes, notario público del rey en Salamanca, porque yo he mandado del rey que signe las cartas et los testamentos et los contratos que fueron fechos por Domingo Pérez, notario, los que fallar en los sus registros que me pedieren et porque este testamento yo fallé en un registro de los testamentos que fue deste Domingo Pérez et, otrosí, porque Iohán Lucas, alcalde por Alfonso Arnáldez, iuez por el rey en Salamanca, me constrinnió et me mandó que lo fiziese, segund que lo fallase en el registro, a ... ${ }^{129}$.
\end{abstract}

Su interés estriba en sancionar la existencia de registros temáticos, conocida para Castilla en el supuesto de los testamentos ${ }^{130}$, como es el caso que nos ocupa. Ahora bien, resulta imposible deducir si con el término registro se alude a una segunda redacción intermedia, más extensa que la nota, (registro es su nombre técnico ${ }^{131}$ ), establecida por Espéculo, o a un libro de notas de testamentos con una extensión ligeramente abreviada. No obstante, lo habitual en Castilla fue sustituir los libros-registro por simples hojas de registro que se incluían entre los folios del libro de notas y sólo en el supuesto de escrituraciones complejas ${ }^{132}$.

\title{
2.2.3. "Ingrossatio" (redacción en limpio)
}

La extensión definitiva del documento ${ }^{133}$ (carta, carta pública o instrumento público) a partir de la nota o, en su caso, del registro - por lo

${ }^{128}$ M.D. ROJAS VACA, Op. cit.

${ }^{129}$ J.L. MARTín Martín et ALiI, Op. cit., doc. 397 (1285), p. 500.

${ }^{130} \mathrm{~J}$. BONO HUERTA, Breve introducción, p. 40.

${ }^{131}$ Vid. J. BONO HuERTA, Modos textuales, pp. 84-86.

${ }^{132}$ Ibidem, pp. 85-86.

${ }^{133}$ Vocabulaire, p. 90, 363: «Ingrossar ... es la operación que consiste en escribir, después de la minuta 0 , eventualmente, de un borrador, la grossa o la expedición». 
demás no necesaria ${ }^{134}$ - la efectúa bien el propio escribano público autorizante, bien el sustituto o el amanuense que está bajo sus órdenes.

Parece que existe, para Castilla la Vieja, una cierta relación entre el tipo de escribano público autorizante y su participación o no en la labor de ingrosar ${ }^{135}$ el documento.

Así, de ordinario, los escribanos públicos del concejo y los de la iglesia, salvo excepciones ${ }^{136}$, se ocupan, personalmente, de poner por extenso, en limpio, el documento:

Et yo, Gonçalo Pérez, escriuano público de Burgos, fiz esta carta e en ella mýo signo ${ }^{137}$.

Et, porque esto non venga en dubda, mando fazer esta carta a Pero Martínez, escriuano público del conceio de Valladolit... Yo, Pedro Martínez, el dicho escriuano, por mandado de don Domingo, el dicho vendedor, fiz esta carta et fiz en ella mío signo (signo) en testimonio ${ }^{138}$.

Yo, Gil Yuannes, escrivano público, la escriví et fiz este mi signo en esta $\operatorname{carta}^{139}$.

Et, porque esto sea firme et non venga en dubda, nos, los dichos don Matheos et donna Eluira, rogamos a Martín Velasco, público escriuano del Cabildo de la eglesia de Valleolit (sic), que nos faga de tod esto un público instrument... Et yo, el dicho Martín Velasco, público escriuano rogado, ui et fuý present a tod esto et con mi mano propia fiz este público instrument et pús en él mío sig(signo)no en testimonio rey geste ${ }^{\mathrm{I} 40}$.

\footnotetext{
${ }^{134} \mathrm{~A}$ veces al actor $\mathrm{y}$, en su caso, al destinatario les bastaba con la nota del registro que el notario conservaba, según consta en J. BONO HUERTA, Historia del Derecho, I. 1, p. 186: "Este valor sustantivo de la imbreviatura fue reconocido de hecho en el tráfico jurídico, y por ello no fue raro que la parte contractual interesada, después de formalizada la imbreviatura, renunciara de momento a la expedición del $i$. publ. ya que podía obtenerlo sin más en caso de precisarlo".

${ }^{135}$ Vocabulaire, p. $90,363$.

${ }^{136}$ L.M. Villar García, Catedral de Segovia, doc. 239 (1296).

${ }^{137}$ F.J. PEREDA Llanera, Catedral de Burgos, doc. 64 (1263).

${ }^{138}$ M. MAÑueco Villalobos y J. Zurita Nieto, Colegial de Valladolid, doc. LXV (1275).

${ }^{139}$ L.M. Villar García, Catedral de Segovia, doc. 185 (1272).

${ }^{140}$ M. Mañueco Villalobos y J. Zurita Nieto, Colegial de Valladolid, doc. LXVI (1275).
} 
Et, porque esto sea firme...rogamos a Domingo Blasco, conpannero et notario público de la eglesia de Segovia, que fiziese esta carta... et yo, el sobredicho notario, por ruego... escribi esta carta en que fise este mi signo en testimonio ${ }^{141}$.

Yo, el dicho Garçi Fernández, sochantre e escrivano público de la eglesia sobredicha de Ávila, fuý presente a esto sobredicho, en uno con los testigos que dichos son, e por ruego del dicho Munno Matheos escrevi ende este instrumento con mi mano e fiz en él este mi sig(signo)no en testimonio de verdat ${ }^{142}$.

También los sustitutos ad vicem, con frecuencia, escriben por sí mismos:

Et, porque esto sea firme et non venga en dubda, yo, Gonçal Yuanes, et yo, Diego Royz, (i.e. vendedor y fiador) los sobredichos, mandamos a Bartolomé Domínguez, escriuano público del conçeio de Valladolit por Marchos Pérez, que ficiesse esta carta... Yo, Bartolomé Domínguez, el dicho escriuano, fiz esta carta et pús en ella mýo signo (signo) en testimonio ${ }^{143}$.

Yo, Yuannnes Estevan, escrivano público en Ávila por Estevan Pérez, escrivano público por el rey en este mismo logar, escreví esta carta e fiz en ella este mi sig(signo)no en testimonio ${ }^{144}$.

Mientras, los escribanos públicos reales, aunque excepcionalmente afirman escribir ${ }^{145}$, suelen relegar la extensión de la carta que suscriben a meros amanuenses, permaneciendo estos últimos en total anonimato ${ }^{146}$ :

${ }^{141}$ L.M. Villar García, Catedral de Segovia, doc. 234 (1295).

${ }^{142}$ A. Barrios García, Catedral de Ávila, doc. 167 (1296). (1279).

${ }^{143}$ M. MaÑUeco Villalobos y J. ZuRITA Nieto, Colegial de Valladolid, doc. LXXIII

${ }^{144}$ A. Barrios García, Catedral de Ávila, doc. 151 (1291).

${ }^{145}$ «Et yo, Iohán Pérez, escriuano público por el rey en la cipdat de Burgos, ... a pedimiento del dicho obispo escriuí de todo lo sobredicho esta carta (signo) e pús en ella mío signo en testimonio de verdat» [F.J. Pereda Llanera, Catedral de Burgos, doc. 325 (1299)].

${ }^{146} \mathrm{Y}$ ello al margen de su actuación mediante sustitutos en cuyo caso son éstos los que escriben la carta. 
Yo, Nicolás, escrivano público a la merçed del rey en Segovia, la fiz escrivir et fiz y este mi signo en testimonio ${ }^{147}$.

Yo, Johán Fernández, escrivano público en Ávila por el rey, la fiz escrivir e pús en ella mío sig(signo)no en testimonio ${ }^{148}$.

Considerados en conjunto, la mayoría de los notarios de Castilla la Vieja, con la excepción casi sistemática de los reales, escriben los documentos además de autorizarlos con su suscripción y signo. La función escrituraria que efectúan, por lo demás prescrita legalmente ${ }^{149}$, es afín a la realizada por los de otros concejos del reino de Castilla, cuales Santander y La Rioja ${ }^{150}$. Contrasta, por contra, con la práctica seguida, de ordinario, en Asturias ${ }^{151}$, en la capital del reino de León ${ }^{152} \mathrm{y}$, dentro de éste, en Bembibre ${ }^{153}$, en Benavente ${ }^{154}$ y en Salamanca ${ }^{155}$ así como, con carácter menos constante, en Sevilla ${ }^{156}$. Por tanto, en estos últimos lugares se anticipa una praxis sólo

${ }^{147}$ L.M. Villar García, Catedral de Segovia, doc. 207 (1285).

${ }^{148}$ A. BArrios García, Catedral de Ávila, doc. 139 (1289).

${ }^{149}$ Fuero Real 1, 8, 7: «nengún escriuano non meta otro escriuano que escriua en su lugar, mas cada uno faga sus cartas por su mano».

${ }^{150}$ Caso de Santo Domingo de la Calzada: «Domingo Pérez, escribano público del conçeio de Santo Domingo de la Calzada, ... esta carta con mi mano scripsi e pús en ella mío signo», F.J. Pereda Llanera, Catedral de Burgos, doc. 170 (1282). Vid., asimismo, R.M. BlasCo MARTíneZ, La tardía implantación, p. 27, notas $\mathrm{n}^{\circ} .33,34$ y 35, recogiendo lo consignado en LóPEZ DE SILANES, SANZ RIPA, Colección diplomática calceatense. Archivo de la Catedral. 11251397, Logroño, 1985.

${ }^{151}$ Los documentos notariales asturianos, con frecuencia, fueron materializados por simples amanuenses, según consta en M.J. SANZ FUENTES, Op. cit., p. 252.

${ }^{152}$ J.A. MARTín Fuertes, Los notarios en León, p. 611. Asimismo, vid. R.M. BlasCo MARTíNEZ, La tardía implantación, p. 29, nota 52.

${ }^{153}$ «Yagüe Díaz que escreuí esta carta con mi mano ... por ruego de Pedro Iuannes, escriuano público del conçeio de Bembibre. Yo, Pedro Iuannes, la fiz escrivir», F.J. PEREDA LlaNERA, Catedral de Burgos, doc. 167 (1280).

${ }^{154}$ J.L. MARTín MARTín ET ALII, Op. cit., doc. 466 (1300).

${ }^{155}$ Ibidem, caso de Iohán Escrivan (docs. n ${ }^{\circ}$. 321, 326, 329, 331, 333, 335, 336, 340, 342 , $347,350,351,354,355,361,362,363,381,390,392,393,394,402,406,409$, 421, de $1268-$ 1289), Domingo Pérez (en docs. 338, 339, 344, 345, 346, 348, 357, 359, 360, 364, 368, 371, $379,380,382,386,397,404$, de 1273-1286), por citar tan sólo a dos de los notarios salmantinos más activos.

${ }^{156}$ P. Ostos-M.L. PARDo, Documentos y notarios de Sevilla, p. 42. 
permitida legalmente por Sancho IV en $1293^{157}$ que, al menos hasta 1300 , no es habitual en esta zona, según se desprende de la documentación examinada.

En cualquier caso, para la confección del mundum el notario o, en su caso, el escribiente bajo sus órdenes, se auxilió de formularios y en ello incide el tono reiterativo de las formas empleadas en los documentos. Sin embargo, aunque éstos, especialmente los de final del siglo, participan de la estructura y estilo común a los insertos en los formularios coetáneos, - (regestas de Espéculo y fórmulas de Partidas) ${ }^{158}$-, resulta evidente que no constituyeron una aplicación, sin más, de los mismos. De la comparación de los modelos de Partidas con los documentos examinados se comprende que tales fórmulas no fueron la fuente directa de imitación de aquéllos pues denotan un mayor arcaísmo ${ }^{159}$. Es muy probable que, como han señalado Olivier Guyotjeannin, Jacques Pycke y Benoît-Michel Tock, fueran "en general personales, constituidos poco a poco por la experiencia"160.

\subsection{4. "Recognitio" (Revisión)}

La revisión de la carta para corregir errores de fondo o forma ${ }^{161} \mathrm{o}$, en ausencia de mención expresa, su reflejo gráfico, a saber: la «salvadura de yerros», prescrita legalmente ${ }^{162}$, consta en muy escasos ejemplares, pese a la existencia de no pocas enmiendas. Sólo un ejemplar de Valladolid y otro de Ávila se hacen eco de ella. La salvadura se sitúa, en el primero, antes de la suscripción notarial y, en Ávila, tras ella. El mismo escribano público es el autor del salvado de enmiendas, formulándose como sigue:

\footnotetext{
${ }^{157} \mathrm{~J}$. BONO HUERTA, Breve introducción, p. 30.
}

${ }^{158} \mathrm{Cfr}$. J. GARCía-Granero FernÁNDEZ, Formularios notariales de los siglos XIII al XVI, "Anales de la Academia Matritense del Notariado", XXII/1 (Madrid, 1978), pp. 227-286 y, para Castilla-León, especialmente, pp. 269-274. Igualmente, cfr. J. BONO HUERTA, Historia del Derecho, I. 1, pp. 241-256 (para situar las fórmulas incluidas en Espéculo y Partidas) y, del mismo autor, Historia del Derecho, I.2., pp. 59-72, en lo que respecta a "La Literatura notarial nacional-castellana" de formularios, éstos de fines del siglo XIV y del siglo XV.

${ }^{159}$ Algo que, al comentar los modelos de Partidas, pone de manifiesto J. BONO HuERTA, Historia del Derecho, I. 1, p. 246.

${ }^{160}$ O. Guyotjeannin, J. Pycke, B.M. Tock, Op. cit., p. 243.

${ }^{161}$ Vocabulaire, p. 91, 365.

${ }^{162}$ Espéculo, 4, 12, 7 y Fuero de Soria 80. 
Este instrumento es entrelineado sobre el vicéssimo sesto renglón et non le enpesca $^{163}$.

En este instrumento a quinze renglones contados desde çima está puntada una parte que es sobejana que dizen fueron e non enpezca por esto ${ }^{164}$.

\subsection{5. "Validatio" (Validación)}

Supone la validación un momento capital en la génesis del documento pues mediante esta operación "recibe sus signos o marcas de autenticidad, variables según los usos de la cancillería considerada"165 o el oficio de expedición responsable, alcanzando su perfección diplomática. Los documentos notariales examinados se validan, por sistema, mediante las suscripciones de los testigos, de un lado, y la suscripción y el signo del notario, de otro. No recogen las colecciones consultadas suscripción de otorgante alguno.

Las suscripciones de los testigos (denominados «pesquisas» en Valladolid) no son, a tenor de los ejemplares consultados y de la terminología usada, autógrafas. Éstos actúan, según se afirma cuando se menciona, a ruego de los otorgantes, indicando la fórmula anunciadora de la relación, introducida por diferentes comisos, de ordinario, que fueron presentes y/o «uieron e oyeron» simplemente y, con menor frecuencia, además, el momento en que se produjo su intervención: en el momento del otorgamiento o al mandar hacer la carta. Excepcionalmente, se indica que tales testigos lo fueron o estuvieron presentes al leer y hacer público determinado testamento:

E desto son testigos, rogados de amas partes, que lo vieron e que lo oyeron:.... ${ }^{166}$.

Pesquisas que fueron presentes quando estas cartas fueron otorgadas... ${ }^{167}$.

${ }^{163}$ M. MaÑueco Villalobos y J. Zurita Nieto, Colegial de Valladolid, doc. CII (1288).

${ }^{164}$ A. Barrios García, Catedral de Ávila, doc. 167 (1296).

${ }^{165}$ Vocabulaire, p. $91,369$.

${ }^{166}$ F.J. Pereda Llanera, Catedral de Burgos, doc. 140 (1276).

${ }^{167}$ M. MaÑueco Villalobos y J. Zurita Nieto, Colegial de Valladolid, doc. CXVI (1290). 
Testigos que fueron rogados de amos los partes et vieron de cómmo se otorgó que era apoderado et entregado... ${ }^{168}$.

Testigos rogados et llamados ante quien el arcidiano sobredicho otorgó este testamento et rogó a mí (i.e. notario)... ${ }^{169}$.

Testigos que fueron presentes, llamados e rogados, quando $\mathrm{N}$ y $\mathrm{N}(i . e$. donantes) ... mandaron fazer esta carta ${ }^{170}$.

Testigos que fueron presentes, llamados e rogados, quando $\mathrm{N}(i . e$. donatario) ... mandó fazer esta carta ${ }^{171}$.

que vieron e que oyeron esta manda leer e publicar... ${ }^{172}$.

Cabe señalar cómo un documento vallisoletano de donación recoge dos relaciones de testigos distintas, correspondientes a los momentos, también diferentes, en los cuales donatarios y donantes mandaron «fazer» la carta ${ }^{173}$.

El número de testigos es variable. Eventualmente se ajustan al mínimo prescrito por la ley, establecido por Fuero Real en tres «al menos» ${ }^{174}$ y por Partidas en dos, si éstos eran escribanos públicos, o tres, si sólo eran «ommes buenos» ${ }^{175}$, aumentando a siete para el caso de los testamentos ${ }^{176}$. Los documentos abulenses son los que, con mayor frecuencia, reseñan tres testigos. Mientras, en Burgos, Valladolid y Segovia el promedio habitual va de cinco a ocho, advirtiéndose cierta disminución con el tiempo.

${ }^{168}$ L.M. Villar García, Catedral de Segovia, doc. 226 (1281).

${ }^{169}$ Ibidem, doc. 228 (1292).

${ }^{170}$ M. MaÑueCo Villalobos y J. Zurita Nieto, Colegial de Valladolid, doc. XCI (1287).

${ }^{171}$ Ibidem, doc. XCI (1287).

${ }^{172}$ F.J. PEREDA Llanera, Catedral de Burgos, doc. 238, (1292). Testigos de lectura y publicación de otro testamento pero inscritos en documento realizado expresamente con este fin, aunque incorporado a aquél, los encontramos, asimismo, en Valladolid [M. MAÑUECO Villalobos y J. ZuRITA NiETo, Colegial de Valladolid, doc. CII (1288)].

${ }^{173} \mathrm{Vid}$. en la relación precedente las fórmulas correspondientes al doc. XCI de Valladolid.

${ }^{174}$ Fuero Real 2, 9, 1. En Burgos, la cifra de tres tan sólo se advierte en un documento, F.J. Pereda Llanera, Catedral de Burgos, doc. 277 (1292).

${ }^{175}$ Partida 3, 18, 54.

${ }^{176}$ Partida 3, 18, 103. 
Por otro lado, en Burgos es de notar cómo, desde mediados del sesenta, desaparece de la lista de testigos la agrupación tradicional entre clérigos y legos o, en su caso, la de hijosdalgos y hombres buenos, así como toda presencia del concilio o concejo como auditor, veedor y confirmador, usual en los procedentes del fondo de Las Huelgas anteriores a $1254^{177}$.

La suscripción del notario cierra el documento. Los escribanos públicos de Castilla la Vieja, - salvo el caso de los reales cuando actúan mediante sustitutos-, autorizan los documentos con su suscripción autógrafa y su signo:

Et yo, Gonçalo Pérez, escriuano público de Burgos, fiz esta carta e en ella mýo signo ${ }^{178}$.

Et yo, Iohán Pérez, escriuano público por el rey en la cipdat de Burgos, ... a pedimiento del dicho obispo escriuí de todo lo sobredicho esta carta (signo) e pús en ella mío signo en testimonio de verdat ${ }^{179}$.

Yo, Pedro Martínez, el dicho escriuano, por mandado de don Domingo, el dicho vendedor, fiz esta carta et fiz en ella mío signo (signo) en testimonio ${ }^{180}$.

Et yo, el dicho Martín Velasco, público escriuano rogado, ui et fuý present a tod esto et con mi mano propia fiz este público instrument et pús en él mío sig(signo)no en testimonio rey geste ${ }^{181}$.

Yo, Gil Yuannes, escrivano público, la escriví et fiz este mi signo en esta $\operatorname{carta}^{182}$.

Yo, Nicolás, escrivano público a la merçed del rey en Segovia, la fiz escrivir et fiz ý este mi signo en testimonio ${ }^{183}$.

${ }^{177}$ La última mención a éste en un documento del fondo de Las Huelgas, J. M. LizoAín GARrIDO, Huelgas, doc. 448 (1254).

${ }^{178}$ F.J. PEREDA LlanERA, Catedral de Burgos, doc. 64 (1263).

${ }^{179}$ Ibidem, doc. 325 (1299).

${ }^{180}$ M. MaÑUeCo Villalobos y J. ZuRITA NiEto, Colegial de Valladolid, doc. LXV (1275).

${ }^{181}$ Ibidem, doc. LXVI (1275).

${ }^{182}$ L.M. Villar García, Catedral de Segovia, doc. 185 (1272).

${ }^{183}$ Ibidem, doc. 207 (1285). 
Yo, el sobredicho notario, por ruego...escribí esta carta en que fise este mi signo en testimonio ${ }^{184}$.

Yo, Johán Fernández, escrivano público en Ávila por el rey, la fiz escrivir e pús en ella mío sig(signo)no en testimonio ${ }^{185}$.

Yo, el dicho Garçi Fernández, sochantre e escrivano público de la eglesia sobredicha de Ávila, fuý presente a esto sobredicho, en uno con los testigos que dichos son, e por ruego del dicho Munno Matheos escreví ende este instrumento con mi mano e fiz en él este mi sig(signo)no en testimonio de verdat $^{186}$.

Incluso los sustitutos usan signo propio, según denota el posesivo que, en la suscripción, acompaña al anuncio de su aposición:

Et, porque esto sea firme et non venga en dubda, yo, Gonçal Yuanes, et yo, Diego Royz, (i.e. vendedor y fiador) los sobredichos, mandamos a Bartolomé Domínguez, escriuano público del conçeio de Valladolit por Marchos Pérez, que ficiesse esta carta... Yo, Bartolomé Domínguez, el dicho escriuano, fiz esta carta et pús en ella mýo signo (signo) en testimonio ${ }^{187}$.

Yo, Yuannnes Estevan, escrivano público en Avila por Estevan Pérez, escrivano público por el rey en este mismo logar, escreví esta carta e fiz en ella este mi sig(signo)no en testimonio ${ }^{188}$.

Difiere, por tanto, el proceder habitual de estos sustitutos del que adoptan los de otros territorios de la Corona castellano-leonesa donde, de ordinario, el sustituto suele hacer uso del signo del titular-sustituido ${ }^{189}$.

${ }^{184}$ Ibidem, doc. 234 (1295).

${ }^{185}$ A. Barrios García, Catedral de Ávila, doc. 139 (1289).

${ }^{186}$ Ibidem, doc. 167 (1296). (1279)

${ }^{187}$ M. MaÑueco Villalobos y J. Zurita Nieto, Colegial de Valladolid, doc. LXXIII

${ }^{188}$ A. Barrios García, Catedral de Ávila, doc. 151 (1291).

${ }^{189}$ M.J. SANZ FuenteS, Op. cit., p. 253. 
De otro lado, en los documentos notariales de Burgos, Valladolid, Segovia y Ávila el recurso a medios de validación complementarios de los anteriores ${ }^{190}$, cuales el sellado y el sistema de letras partidas no es frecuente.

Las literae divisa aparecen en escasos ejemplares, si bien su empleo excede de los negocios prescritos por las leyes, cuales la permuta ${ }^{191}$, el depósito $^{192}$ y el censo ${ }^{193}$. Las encontramos, preferentemente, en permutas ${ }^{194}$ pero también, aunque en menor proporción, en transacciones ${ }^{195}$, $\operatorname{censos}^{196} \mathrm{y}$ en alguna donación ${ }^{197}$, compraventa ${ }^{198}$, testamento ${ }^{199}$ y entrega de legado ${ }^{200}$, en estos últimos quizá debido al interés de los legatarios, dadas las particulares condiciones a que se sujetan los correspondientes mandas y legados.

Por su parte, la presencia de sellos pendientes, a veces asociado con el sistema de carta partida, se detecta en escasos ejemplares. Siempre cuando los otorgantes o personas relacionadas con éstos u otras implicadas en el asunto que se escritura son dignidades o instituciones, especialmente, eclesiásticas pero, también, laicas que disponen de sello propio. Es el caso, por poner un ejemplo, del testamento otorgado por un arcediano burgalés que, al margen de ir sellado con el sello de éste, va provisto de los sellos de los

\footnotetext{
${ }^{190}$ Sobre su significado vid. M. LUCAS ÁLVAREZ, El notariado en Galicia, pp. 368-369.

${ }^{191}$ Espéculo 4, 12, 36.

${ }^{192}$ Espéculo 4, 12, 43.

${ }^{193}$ Partida 3, 18, 69.

${ }^{194}$ M. MAÑUECo VILlaLobos y J. ZURITA NIETo, Colegial de Valladolid, docs. LXII (1268), LXXIV (1280), LXXXIII (1285), CVII (1289) y A. BARRIOS GARCÍA, Catedral de Ávila, doc. $92(1268)$.

${ }^{195}$ M. MaÑueco Villalobos y J. Zurita NiETo, Colegial de Valladolid, doc. LVII (1263) y CXVI (1290).

${ }^{196}$ F.J. PEREDa Llanera, Catedral de Burgos, doc. 345 (1300) y M. MAÑUeCo VIlllalobos y J. ZURITA NIETO, Colegial de Valladolid, doc. LXI (1268). (1281)

${ }^{197}$ M. MAÑueCo VILlalobos y J. ZURITA NiETo, Colegial de Valladolid, doc. LXXVII

${ }^{198}$ L.M. Villar García, Catedral de Segovia, doc. 165 (1258). (1279).

${ }^{199}$ M. MaÑueCo Villalobos y J. ZuRita Nieto, Colegial de Valladolid, doc. LXXII (1299).

${ }^{200}$ M. MaÑueco Villalobos y J. ZuRita Nieto, Colegial de Valladolid, doc. CXXXII
} 
albaceas entre los cuales se encuentran el obispo, un arcediano, un abad, un arcipreste y el capellán del otorgante ${ }^{201}$.

\subsection{6. "Traditio" (Libramiento)}

La entrega de la carta a la parte interesada $\left(\operatorname{librar}^{202}\right)$, previo pago o promesa de abonar los correspondientes derechos ${ }^{203}$, representa, en palabras de A. Pratesi, "la conclusión del proceso formativo del documento"204. Esta fase queda prevista y reflejada, expresamente aunque de modo excepcional, en el tenor de algunos documentos de Burgos, Valladolid y Ávila, en la cláusula de corroboración junto al ruego/mandato de signado y escrituración al modo que sigue:

\footnotetext{
$\mathrm{E}$, porque esto non venga en dubda, yo, donna Mary Iohán, ruego e mando $a$ vos, Iohán Pérez, escriuano público de Burgos, que fagades desto carta $\mathrm{e}$ que la dedes a don Esteuan, mýo marido ${ }^{205}$.

Et, porque esto sea firme et non venga en dubda, yo, el prior sobredicho, mandé a Bartolomé Domíngues, escriuano público de la dicha eglesia, que fisiesse esta carta et que la diesse a Gonçal Yoanes et a Sancha Marcos, los sobredichos ${ }^{206}$.

E, porque esto sea firme e non venga en dubda, ruego a vos, Johán Pérez, que la registedes e dedes ende al dicho don Yagüe vn estumento (sic) signado con vuestro signo ${ }^{207}$.
}

${ }^{201}$ F.J. Pereda Llanera, Catedral de Burgos, doc. 142 (1277).

${ }^{202}$ Vocabulaire, p. 93, 376

${ }^{203}$ Ninguna anotación marginal recogen las colecciones consultadas al respecto de los derechos debidos al notario por la expedición de la carta. Sin ser una constante, podrían llevarla, según práctica constatada para Asturias por M.J. SANZ FUENTES, Op. cit., p. 253: "al pie del documento, tangentes al borde inferior del pergamino". En ausencia de mención expresa remitimos a los aranceles incluidos en Fuero Real 1, 8, 1, Espéculo 4, 12, 60 y Partida 3, 19, 15.

${ }^{204}$ A. PRATESI, Op. cit., pp. 55-56.

${ }^{205}$ F.J. Pereda Llanera, Catedral de Burgos, doc. 280, (1292).

${ }^{206}$ M. MaÑueco Villalobos y J. ZuRita NiEto, Colegial de Valladolid, doc. C, (1288).

${ }^{207}$ AHN, Sección Clero, "Ávila. Catedral. Pergaminos", carpeta 22, nº . 5. Cfr. A. BARRIOS GarcíA, Catedral de Avila, doc. 131 (1285). 
Sin embargo, una última formalidad completa el iter genético de algún documento. Afecta a un tipo jurídico específico, el testamento, y es su publicación ${ }^{208}$. Dos son los testamentos que recogen esta formalidad: uno es un testamento burgalés que la menciona, sin más, al relacionar los testigos ${ }^{209}$. $\mathrm{El}$ otro, de Valladolid, la reseña en diligencia margina ${ }^{210}$. Al parecer, el testamento en cuestión fue presentado por el notario al alcalde en sustitución de los albaceas ante la posible expiración del plazo prescrito por las leyes para efectuarla y, en consecuencia, la pérdida del legado por parte de la institución beneficiaria $^{211}$. Al no poder cumplir tal requisito los albaceas por estar enfermos, pidió la publicación del testamento el propio escribano público del cabildo, a cuya institución, como principal legataria, interesaba su cumplimiento:

\begin{abstract}
Ante Domingo Nieto, alcalle en Valladolit, Johán Alffonso, escriuano público de la eglesia de Valladolit, apresentó este testamento ante que se conpliessen los treynta días que el dicho Gonzalo Pérez finó, por rasón que disíe que Ferrant Yuannes e donna Constança (i.e. albaceas) estaban dolientes et non podíen uenir ante los alcalles. Et, el dicho alcalle fisol leer et publicar, assí commo manda el Fuero... Et yo, Fernand Péres, escriuano público de Valladolit, fuý presente et leý este testamento ante el dicho alcalle...212
\end{abstract}

\footnotetext{
${ }^{208}$ Vocabulaire, p. 93, 377: "La publicación de un documento es la formalidad que consiste en dar a conocer públicamente su tenor". Cfr. J. BONO HUERTA, Modos textuales de transmisión del documento notarial medieval, "Estudis Historics i Documents dels Arxius de Protocols", XV (Barcelona, 1997), p. 33.

${ }^{209}$ F.J. Pereda Llanera, Catedral de Burgos, doc. 238 (1290).

${ }^{210}$ M. MaÑueco Villalobos y J. Zurita NiETo, Colegial de Valladolid, doc. CII (1288).

${ }^{211}$ Fuero Real 3, 5, 13: «Todo omne que fuer cabeçal dalguna manda, muéstrela antel alcalde fata I mes e el alcalde fágala leer conçegeramientre; e si el cabeçal esto non fiziere, pierda aquéllo que deue auer de la manda e dénlo por ánima del muerto; e esto sea de todo otro omne que touiere la manda, maguer non sea cabeçal. E, si ninguna cosa non ouiere en la manda, peche el diezmo de la manda».

${ }^{212}$ M. Mañueco Villalobos y J. Zurita Nieto, Colegial de Valladolid, doc. CII (1288).
} 


\section{FORMA}

\subsection{Caracteres externos}

Los documentos notariales examinados, aquéllos a los que hemos tenido acceso, se extienden sobre pergamino de formato variable. Se escriben por la pars munda o parte de la carne, con los renglones paralelos, de ordinario al lado más largo aunque también encontramos ejemplares con líneas paralelas al borde menor. En algunos se aprecia pautado horizontal a punta seca.

La disposición del texto sobre el soporte es uniforme sin partes destacables pues ni la relación de testigos, contrariamente a lo que sucede en Sevilla $^{213}$, ni la suscripción notarial forman párrafo aparte.

Las escrituras usadas, sin entrar en más consideraciones, se adscriben a la tradición de las góticas castellanas con tipos tanto semicursivos como cursivos $^{214}$. Han abandonado, por tanto, la carolina gotizada de la primera mitad del siglo XIII.

Los elementos figurados son escasos. De ellos sobresale el signo manual que, con la cronología antes apuntada, (1255 en Valladolid, 1257 en Burgos, 1258 en Segovia y 1263 en Ávila), se convierte en "aditamento ineludible de la suscripción"215 del notario y, para el caso de Castilla la Vieja, habida cuenta de la falta de precedentes, en el carácter más definitorio del notario y del documento notarial.

Habitualmente, el signo se sitúa en la última línea, correspondiente a la suscripción del notario, ya subsumido en ésta, cortando por la mitad la palabra signo o sustituyéndola por su imagen, ya al final de la misma. No obstante, en los ejemplares burgaleses más antiguos tiende a quedar enmarcarcado dentro del texto, dejando varios renglones de escritura por la parte inferior y coincidiendo el comienzo del trazado con el final de la data crónica

${ }^{213}$ P. OSTOS-M.L. PARDo, Documentos y notarios de Sevilla, pp. 91-92.

${ }^{214}$ Vid., al respecto, M.J. SANZ FuENTES, Paleografia de la Baja Edad Media castellana, "Anuario de Estudios Medievales", 21 (Barcelona, 1991), pp. 527-536 y, asimismo, M.C. DEL CAmino, La escritura de los escribanos públicos de Sevilla, "Historia. Instituciones. Documentos", 15 (Sevilla, 1988), pp. 145-165.

${ }^{215} \mathrm{~J}$. BONO HUERTA, Breve introducción, p. 50. 
y el inicio de la data personal o, en ausencia de esta última, de la suscripción del notario. En caso de ir al final de la suscripción enlaza con la línea de cierre que suelen incluir la mayoría de los documentos.

Su presencia constante invita, al menos, a un somero análisis de los mismos, máxime cuando, además de su incuestionable condición de medio de validación, manifiestan la suficiente iconicidad y esmero de realización como para inscribirlos, por factura y significación, en el contexto cultural gótico, tanto de la escritura como de la imagen: grafismo limpio, cuidado, tanto si obedece a un diseño naturalista cuanto si depende del gusto por la lacería o entrelazado geométrico. En uno y otro caso cabría hablar ya de un carácter simbólico, ya, sin más, del "gusto gótico por la moda «sarracena»" 216 por citar la posible influencia más próxima ${ }^{217}$ : medallones, círculos foliados con sépalos radiales (en otro nivel, visión paralela a la de los rosetones de las portadas de las iglesias), estrellas de ocho puntas, polígonos y cruces, resultantes del cruzamiento multiplicado de cadenas, etc.

$\mathrm{Al}$ respecto, si bien, en líneas generales, resulta difícil establecer las fronteras entre lo que es mero ornamento y lo que pretende ser símbolo ${ }^{218}$, queda claro para ambos casos el deseo de llamar la atención, de detener la lectura y acentuar nuestra mirada, de "significar" en suma, independientemente del grado más o menos elaborado del diseño.

Dado, pues, el carácter consciente de su llamativa inserción, podemos detenernos para destacar, por inusuales, los siguientes signos:

Los escudos, con su dibujo tomado en préstamo de la heráldica del momento, forma redondeada, campo bandado ( 2 y 3 diagonales descendentes de izquierda a derecha para el observador o diestra/siniestra según el propio escudo), un diseño apropiado según patrón de caballería pero que, en

${ }^{216}$ Cfr. J. BALtruSAitis, La Edad Media Fantástica, Madrid, 1983.

${ }^{217}$ A. RIEGL, Problemas de Estilo. Fundamentos para una historia de la ornamentación, Barcelona, 1980, p. 173, se refiere al lazo de cinta, muy utilizado en el arte musulmán pero que, no obstante, es originario de la cinta trenzada, común en el mundo antiguo-oriental y, después, también usada con profusión entre griegos y, especialmente, romanos llegando a ser "indiscutible motivo principal de la decoración por el arte de la Antigüedad tardía, que hace retroceder lo significativo, situando en primera línea de la creación artística la tendencia decorativa pura. De ahí que conmuevan los entrelazamientos de cinta en los sarcófagos y ambones paleocristianos... de ahí los almocárabes bizantinos..."

${ }^{218}$ Ibidem. Cfr., asimismo, los trabajos dedicados a los signos notariales en P. RÜCK (Ed.), Notarssignete, "Graphische Symbole in mittelalterlichen Urkunden. Beiträge zur diplomatischen Semiotik", Sigmaringen, 1996, pp. 669-831. 
principio, consideraremos como mera influencia formal y carente de interpretación genealógica o comunal alguna ${ }^{219}$.

El castillo, permanente símbolo de fortaleza, solidez o perennidad, como la "Jerusalén Celestial"220, y que, no obstante, en nuestro caso, más tendría que ver con el tradicional blasón de Burgos y de Castilla ${ }^{221}$.

La llave, alusión a "cerradura" y, consecuentemente, símbolo válido para poner de manifiesto el carácter de guardián de la verdad que el escribano o notario implica con su actividad profesional. Por añadidura, también alude a Dios, garante del bien de nuestra casa o alma y, especialmente, de nuestra $\mathrm{fe}^{222}$, así como a San Pedro, quien recibió la llave o llaves en cuestión directamente de las manos de Cristo ${ }^{223}$.

La flor de lis, por su parte, en cuanto símbolo, puede aludir a la "vida en pureza, promesa de salvación e inmortalidad"224, adecuado, pues, al culto a la Virgen, tan de los nuevos tiempos del gótico. En cuanto diseño, podría obedecer a una popularización del signo real francés, ya conocido y que, algo más tarde, alcanzaría su definitivo canon en el vecino estado ${ }^{225}$.

En fin, independientemente de su condición debida al gusto ornamental, al igual que sucede con la estrella de seis puntas o estrella de David, una y otra, lirio y astro, en el Medioevo aluden a la conciliación de dos realidades contradictorias: el orden natural y el sobrenatural. Según el Talmud, la estrella reflejaba el equilibrio y la armonía de opuestos, estrella que, por otra parte, la tradición consideraba creación del muy sabio rey Salomón. En cuanto a la flor de lis o lirio, aludía a Cristo redentor, hombre a la vez que Dios, quien nos asegura, además, la promesa de poder acceder a lo sobrenatural, al Paraíso, al fin de nuestros días ${ }^{226}$.

${ }^{219} \mathrm{Vid}$. figs. 3.a y 3.b. 1980.

${ }^{20} \mathrm{Cfr}$. F. GARNIER, Le langage de l'image au Moyen Âge. II. Grammaire des gestes. Tours,

${ }^{221}$ Vid. fig. 4.

${ }^{222}$ Cfr. A. BERnAt Vistarini y J.T. Cull, Emblemas Españoles Ilustrados, Madrid, 1999.

${ }^{223}$ Vid. fig. 5.

${ }^{224} \mathrm{Cfr}$. A. Bernat Vistarini y J.T. Cull, Op. cit.

${ }^{225}$ Vid. fig. 7.

${ }^{226}$ Vid. fig. 6. 


\subsection{Caracteres internos}

\subsubsection{Elementos de redacción (lengua y estilo)}

Los documentos notariales examinados se redactan en castellano con las excepciones representadas, especialmente, en los ejemplares más antiguos $\mathrm{y}$, de modo ocasional, en los de final de siglo por la invocación verbal, determinada notificación ${ }^{227}$, el incipit de la data, la fórmula que introduce la expresión del año por el sistema de la era cristiana (habitual en los documentos burgaleses hasta fines del setenta y, excepcional, en los de Valladolid ${ }^{228}$ y Segoviaa $^{229}$ ) y alguna suscripción notarial. Cabe señalar, asimismo, la redacción latina de las fórmulas iniciales del testamento otorgado por un arcediano de Burgos (1277) $)^{230}$ que abarca, además de la invocación verbal, el preámbulo, la intitulación, la fórmula de espontaneidad y el comienzo de la disposición.

La forma de redacción dominante es la subjetiva (primera persona) pero en el último tercio del siglo cuatro documentos se conciben en forma objetiva (tercera persona), a saber, dos compraventas de Segovia y dos actas, una de intima y otra de atestación, en Burgos.

\subsubsection{Elementos del discurso diplomático}

Considerando en su conjunto el tenor de los documentos examinados observamos que son dos las estructuras (estructura $=$ orden y distribución del formulario) documentales usadas por nuestros notarios para envolver el contenido de los documentos que autorizan, conectadas con su también doble forma de redacción. Una, denominada de carta, dominante, propia de los documentos redactados en forma subjetiva y otra, llamada de acta por su

\footnotetext{
${ }^{227}$ F.J. Pereda Llanera, Catedral de Burgos, doc. 86 (1267) y D. MANSILla ReOYo, Catálogo, doc. 773 (1267).

${ }^{228} \mathrm{M}$. MAÑUeCo Villalobos y J. ZURITA Nieto, Colegial de Valladolid, docs. LXI (1268) y LXIII (1271).

${ }^{229}$ L.M. Villar García, Catedral de Segovia, docs. 186 (1272), 234 (1295), 239 (1296) y 240 (1297).

${ }^{230}$ F.J. Pereda Llanera, Catedral de Burgos, doc. 142 (1277), pp. 200-204.
} 
afinidad con las homónimas reales ${ }^{231}$, minoritaria y usada para documentos concebidos en forma objetiva ${ }^{232}$.

\subsubsection{Cartas}

Durante la primera mitad del siglo XIII, en Burgos, - salvo excepciones y partiendo de supuestos típicos (documentos de enajenación de inmuebles, los más frecuentes)-, notamos la convivencia, aunque en proporción desigual, de dos moldes estructurales diferentes, bajo una forma única de redacción, la subjetiva.

Uno, muy simple, mayoritario ${ }^{233}$, y otro, más complejo, minoritario y anunciador de la estructura característica del documento notarial bajomedieval ${ }^{234}$. En el primero, el orden y distribución del formulario es el que sigue: la invocación verbal abre el tenor. Tras ella se sitúa la intitulación, sin partícula de enlace alguna. A continuación, la disposición lleva la dirección subsumida y recoge las circunstancias del negocio. Tras la disposición se desarrollan las cláusulas de sanción penales espirituales que amenazan al infractor con, de ordinario, la maldición y la excomunión. Las cláusulas de sanción penales temporales, sistemáticamente, la multa pagadera al monarca y la de restitución doblada al adquirente del bien transmitido con, a veces, las mejoras introducidas son, salvo excepciones ${ }^{235}$, las únicas consideradas. La data crónica, mencionando tan solo mes y año, y la data personal así como la lista de testigos y la suscripción del scriptor cierran el tenor de estos documentos ${ }^{236}$.

Al mismo tiempo, si bien con una representación absolutamente inferior, determinados scriptores usan una estructura algo más compleja que,

\footnotetext{
${ }^{231}$ A.C. Floriano Cumbreño, Curso general de Paleografía y Paleografía y Diplomática españolas, I, Oviedo, 1946, p. 545.

${ }^{232}$ P. Ostos-M.L. PARdo, Documentos y notarios de Sevilla, p. 191.

${ }^{233}$ Vid., a modo de ejemplo, J.M. LizOAín GARRIDO, Huelgas, doc. 499 (1256).

${ }^{234} \mathrm{Vid}$., a modo de ejemplo, J.M. LizoAín GarRIDO, Huelgas, doc. 405 (1250).

${ }^{235}$ Son mínimos los documentos que, bajo esta estructura, incorporan la cláusula de fianza.

${ }^{236} \mathrm{Cfr}$. J. BONO HuERTA, Breve introducción, pp. 53-54. Salvo ligeras variantes, este esquema estructural es el que observan los documentos privados gallegos e, inicialmente, los leoneses antes de la expansión del notariado, según reseñan, M. LuCAS AlVAREZ, Documentos notariales y notarios, pp. 228-229 y J.A. MARTín FUERTES, Los notarios en León, pp. 602 y 606.
} 
a fines de la década del cincuenta del siglo XIII, terminará por imponerse. Dicha estructura es la siguiente: la invocación verbal encabeza el tenor. Tras ella, la notificación universal (bajo la forma «Notum sit omnibus») da paso, mediante la partícula «quod», a la intitulación, mientras la fórmula de espontaneidad hace lo propio con la disposición. Con ciertas variantes de contenido, las sanciones antedichas cierran el texto. Además se suma, con frecuencia, la cláusula de fianza que se formula, cuando algo se menciona, según la costumbre local o al "fuero de la tierra". Sin embargo, conviene destacar la sustitución de la sanción penal espiritual que conminaba al infractor con la maldición y la excomunión por la ira divina y, en la data crónica, la adición del día del mes por el sistema de los días andados y por andar. Las restantes fórmulas son las mismas que en los documentos anteriores.

Bajo este último molde, denominado de $\operatorname{carta}^{237}$, pues el primero desaparece, enriquecido por adición de ciertas fórmulas y renovado por desarrollo/modificación del contenido de las existentes o eliminación de otras, se redactarán la mayoría de los documentos notariales desde finales de la década de los cincuenta del siglo XIII en Burgos, Valladolid, Segovia y, desde comienzos del sesenta, en Ávila, así como en los demás territorios de la Corona castellano-leonesa ${ }^{238}$. Todos los cambios aludidos no se producirán de una vez ni en la misma cronología, irán imponiéndose paulatinamente y, de ordinario, su desarrollo afectará de manera "diferente" al documento según el tiempo y el espacio considerados e, incluso, la formación del notario. No obstante, es posible trazar los caracteres que delimitan la forma interna básica del documento notarial en los momentos de su inicial andadura y, sobre todo, seguir el proceso de ajuste "al nuevo pensar jurídico que difunden los textos legales alfonsinos"239 que hasta el siglo XIV no se consuma ${ }^{240}$, sopesando la mezcla de "continuidad e innovación"241 que le caracteriza.

La invocación verbal, fórmula constante en Burgos hasta 1270, encabeza el discurso de los documentos. Aunque no desaparece, desde 1272

\footnotetext{
${ }^{237}$ P. OStos-M.L. PARdo, Documentos y notarios de Sevilla, p. 191.

${ }^{238} \mathrm{~J}$. BONO HUERTA, La práctica notarial, pp. 501-506.

${ }^{239}$ J. Bono HuerTa, "Prólogo", Documentos y notarios de Sevilla, p. 12.

${ }^{240}$ Ibidem.

${ }^{24 !}$ Cfr. J. BONO HUERTA, La práctica notarial.
} 
entra en franco retroceso en beneficio de la notificación pues figura de forma esporádica, de ordinario, no sólo en testamentos y donaciones, tipos donde en Valladolid, inicialmente ${ }^{242}$, en Segovia ${ }^{243}$ y en Ávila ${ }^{244}$ parece quedar confinada, sino también, con mayor frecuencia, en compraventas y permutas.

Domina sobremanera la invocación al nombre de Dios o, en menor medida, del Señor frente a la que se realiza en el nombre de Cristo, eventual ${ }^{245}$. Puede ir acompañada de la adprecación «Amén» y a lo largo de la segunda mitad del siglo alternarán las formas castellanas con las latinas.

El preámbulo en la documentación notarial analizada consta tan sólo en un testamento burgalés, otorgado por el arcediano y, a su vez, maestro Pedro Pascual. Expresado en latín su contenido respondería, siguiendo la clasificación usada por A. Canellas ${ }^{246}$, a un tipo mixto religioso-jurídico, formulándose como sigue:

Tras la descomposición de la carne, para la disposición de las cosas y por el acometimiento de las costumbres o si, no habiendo lugar para la penitencia, es necesario que ésta llegue por consejo de la providencia ${ }^{247}$.

La notificación, de escasa presencia en Burgos hasta 1256, se convierte en fórmula constante ${ }^{248}$ a partir de 1257 . Sigue, de ordinario, a la invocación y adprecación hasta 1270 e inicia, con frecuencia, el discurso a partir de 1272, faltando aquéllas. En cualquier caso, se trata de una notificación objetiva y universal, cuya formulación varía con el tiempo.

${ }^{242}$ M. MaÑueCo Villalobos y J. Zurita NiETo, Colegial de Valladolid, docs. LXXI (1278) y LXXII (1279), testamentos. No consta en donaciones ni testamentos posteriores.

${ }^{243}$ L.M. Villar GarCía, Catedral de Segovia, doc. 239 (1296), testamento.

${ }^{244}$ A. BARrios García, Catedral de Ávila, doc. 88 (1263), Testamento. Ya no vuelve a aparecer.

${ }^{245} \mathrm{De}$ los examinados sólo un testamento recoge la fórmula de invocación verbal cristológica. Redactada en latín, va seguida de la adprecación y se expresa como sigue: «In nomine nostri Ihesu Christi, amen», F. J. PEREdA LlanerA, Catedral de Burgos, doc. 142 (1277), pp. 200-204, testamento.

${ }^{246}$ A. CANEllas LóPEZ, Diplomática hispano-visigoda, Zaragoza, 1979, pp. 107-108.

${ }^{247}$ F.J. Pereda Llanera, Catedral de Burgos, doc. 142 (1277), pp. 200-204.

${ }^{248}$ Sólo desde entonces carece de toda notificación el testamento otorgado por el arcediano burgalés Pedro Pascual, siendo el preámbulo, previa la invocación verbal cristológica, la fórmula que enlaza con la intitulación en el mismo, F. J. PEREDA LlanERA, Catedral de Burgos, doc. 142 (1277), pp. 200-204. 
La forma dominante hasta 1257 , «Notum sit omnibus», se torna entre 1258 y 1270 , salvo excepciones ${ }^{249}$, «Connosçuda cosa sea» y alterna con «Sepan quantos esta carta vieren» hasta 1278 . Desde 1280 se impone «Sepan».

En Segovia desde 1258, en Valladolid desde 1262 y en Ávila desde 1265 la notificación encabeza, con las excepciones ya citadas ${ }^{250}$, el tenor de los documentos bajo la forma «Connosçuda» hasta 1279, 1275 y 1278, respectivamente, en cada una de ellas, para imponerse a partir de entonces «Sepan».

La intitulación recoge las señas de identidad del actor o actores. Sigue a la notificación ${ }^{251}$ con la cual enlaza mediante las partículas «cuemo» o «como»y, eventualmente, «quod» ${ }^{252}$. Desde que se generaliza el castellano a fines de los cincuenta, salvo excepciones ${ }^{253}$, el pronombre personal «yo» da comienzo a la misma. La forma pronominal «nos» es eventual cuando se trata de intitulaciones conjuntas y más frecuente cuando éstas son colectivas.

Podrá ser la intitulación, por tanto, simple, conjunta o colectiva $a^{254}$.

Siendo simple, los elementos que la componen son, al margen del pronombre, tratamiento, nombre y, con frecuencia, patronímico, título para dignidades eclesiásticas (precedido, cuando se trata del obispo, de la fórmula de derecho divino) o civiles, más filiación. En general observamos cómo la intitulación de particulares se amplía a partir de la década de los cincuenta y, sobre todo, desde los sesenta, con menciones relativas a oficio y concejo de morada e, incluso, barrio.

\footnotetext{
${ }^{249}$ «Notum sit omnibus» es la forma adoptada por la notificación en los documentos burgaleses autorizados por Álvar Abril en 1260 [F.J. PEREDA LLANERA, Catedral de Burgos, doc. 46 (1260), compraventa] y por Domingo Lorent en 1267 [F.J. PEREDA LlanERA, Catedral de Burgos, doc. 86 (1267), compraventa y D. MANSILla REOYo, Catálogo, doc. 773 (1267), p. 199, compraventa].

${ }^{250} \mathrm{Vid}$. fórmula de invocación.

${ }^{251}$ Sólo en el testamento del arcediano burgalés Pedro Pascual la intitulación sigue al preámbulo con el cual enlaza mediante «Ideo", careciendo de fórmula de notificación, [F.J. Pereda Llanera, Catedral de Burgos, doc. 142 (1277), pp. 200-204].

${ }^{252}$ F.J. Pereda Llanera, Catedral de Burgos, doc. 46 (1260), compraventa.

${ }^{253}$ Son excepciones: F.J. PEREDA Llanera, Catedral de Burgos, doc. 142 (1277), pp. 200204 , testamento que conserva el pronombre «ego" pues toda la primera parte del mismo se redacta en latín (invocación, aprecación, preámbulo, intitulación, fórmula de espontaneidad, disposición sobre sepelio y alguna manda) y doc. 46 (1260), compraventa.

${ }^{254}$ Seguimos la terminología usada por A.C. Floriano CUMBREÑo, Op. cit., p. 556.
} 
Los supuestos de intitulación conjunta consignan los mismos elementos con el añadido del vínculo de unión de los actores. Al respecto, son abundantes las intitulaciones conjuntas de cónyuges y, en general, el parentesco domina sobre los vínculos derivados de determinadas actividades.

Normalmente precedida del pronombre personal de número plural «nos», las fórmulas de intitulación colectiva reseñan la institución/es otorgantes del documento, a saber, los cabildos catedralicios, de clérigos parroquiales, prior o abad/esa y cabildo o convento.

Ocasionalmente, amplían la intitulación ciertas fórmulas adicionales orientadas a concretar la actuación de los otorgantes y/o a mostrar los requisitos legales que les capacitan para otorgar el documento ${ }^{255}$. Son éstas las siguientes:

a. Fórmula de mancomunidad

Al fin de concretar el alcance de la obligación contraída por los actores, cuando son varios, responde la fórmula de mancomunidad. Ligada, por tanto, a los supuestos de intitulación conjunta sólo en contados documentos se expresa con claridad su carácter solidario, esto es, de obligación exigible a cualquiera de los deudores por entero ${ }^{256}$ :

amos de mancomún 257 .

amos de mancomún e cada vno de nos por sí e por el todo ${ }^{258}$.

b. Fórmula de representación

Aparece cuando el actor comparece por representante. La concurrencia al otorgamiento mediante representante, supone la identificación primera de éste $y$, tras fórmula anunciadora de la representación, seguidamente, la identificación del actor - representado, según los términos habituales. No se

\footnotetext{
${ }^{255}$ Ibidem, pp. 556-557.

${ }^{256}$ Partida 5, 12, 8.

${ }^{257}$ F.J. Pereda Llanera, Catedral de Burgos, doc. 135 (1276), pp. 189-192, permuta.

${ }^{258}$ F.J. Pereda Llanera, Catedral de Burgos, doc. 214 (1286), pp. 278-279, deuda.
} 
hace en estos documentos mención alguna a la modalidad representativa ostentada:

Nos, ..., en nombre del cabildo 259 .

Nos, por nos e por nuestras mugeres...e por los otros herederos ${ }^{260}$.

c. Fórmula de licencia marital

La fórmula de licencia marital aparece ligada a actores que son mujeres casadas. Viene a solventar las dificultades que, para contratar, encuentra la mujer por razón de sus sexo y estado ${ }^{261}$. Se concreta según consta a continuación:

yo, N..., con plazer e con otorgamiento de mío marido, N... ${ }^{262}$.

La exposición como expresión de motivos concretos no es fórmula constante. La encontramos en documentos de reconocimiento de deuda, pago, compraventa, donación, entrega de legado, transacción y compromiso, antecediendo a la disposición o, con mayor frecuencia, subsumida en ella para explicar la causa que determina la actuación:

por bien de paz, por çierta ciencia et non por yerro ${ }^{263}$.

Et estas casas uos vendo por sentençia de descomunyón que Sancho Yoanes, canónigo de la eglesia de Valladolit et vicario de maestre Gil, prior desa misma eglesia, puso sobre mý fasta que yo fiziesse esta vendida destas casas et diesse los moravedís a los manssessores que él fizo en su testamento para

${ }^{259}$ M. MañueCo Villalobos y J. ZURITA Nieto, Colegial de Valladolid, doc. LXXXIII, 1285, pp. 64-66, permuta).

${ }^{260}$ M. MañueCo Villalobos y J. Zurita Nieto, Colegial de Valladolid, doc. CXXXII, 1299, pp. 323-325, entrega de legado).

${ }^{261}$ Fuero Real 3, 18, 5 y Partida 5, 12, 3.

${ }^{262}$ F.J. Pereda Llanera, Catedral de Burgos, docs. 41 (1258), 43 (1259), 130 (1275) y J.M. LIZOAín GARRIDO, Huelgas, docs. 517 (1260), 518 (1260).

${ }^{263} \mathrm{M}$. MAÑUeCo Villalobos y J. ZuRITA Nieto, Colegial de Valladolid, compromiso inserto en doc. CXXI, 1292, pp. 259-261. 
pagar la menda que fizo pues otros bienes non ý auýe de que se podiesse complir $^{264}$.

\begin{abstract}
uos dó ... por cosas que yo et mýo fijo, Martín Uelasco, auiemos de emendar a uuestra eglesia et después de míos días que nos fagades cada anno tres aniuersarios ${ }^{265}$.

porque lo mandó Ferrant Martínez por su alma en su testamento al cabildo de los canónigos sobredichos ${ }^{266}$.

por rasón del heredamiento que vos ... comprastes ... par cumplir los testamentos de ... mi madre e de ... mi hermano ${ }^{267}$.
\end{abstract}

Por contra, la fórmula de espontaneidad es harto frecuente en los documentos burgaleses. Testamentos ${ }^{268}$, compraventas, donaciones, permutas y alguna deuda la consignan tras la intitulación y previo a la disposición y su uso se mantiene de manera regular hasta finales de siglo:

Estando en mío entendimiento e en mi sana memoria ${ }^{269}$.

de mi bona [buena] uoluntad ${ }^{270}$.

Mientras, en los documentos de Valladolid, Segovia y Ávila la presencia de la fórmula de espontaneidad es excepcional, limitándose su empleo a determinados tipos cuales, con preferencia, testamentos y donaciones:

${ }^{264}$ M. MaÑUeco Villalobos y J. ZuRIta Nieto, Colegial de Valladolid, doc. LXXIII, 1279 , pp. 420-421, compraventa.

${ }^{265}$ M. MaÑueCo Villalobos y J. ZURITA Nieto, Colegial de Valladolid, doc. LXXXII, 1284, pp. 61-62, donación. legado.

${ }^{266}$ L.M. VILlar García, Catedral de Segovia, doc. 197 (1277), pp. 322-323, entrega de

${ }^{267}$ L.M. Villar GARCÍA, Catedral de Segovia, doc. 233 (1295), pp. 365-366, pago.

${ }^{268}$ Seguimos en este sentido el Vocabulaire, pp. 57-58, 201, cuando afirma que a la fórmula de espontaneidad se puede "asimilar las fórmulas testamentarias (tales in mea bona memoria et in mea bona conscientia ...etc.)".

${ }^{269}$ F.J. Pereda Llanera, Catedral de Burgos, doc. 238 (1290), testamento.

${ }^{270}$ F.J. PEREDA LlanERA, Catedral de Burgos, doc. 324 (1299), compraventa. 
estando en mi seso e en mi memoria ${ }^{271}$.

estando en mi entendimiento et en mi memoria qual me Dios quiso dar, saluo la dolençia que Él me dio ${ }^{272}$.

de buen corazón e buena voluntad ${ }^{273}$.

La dirección aparece subsumida en la disposición. Consta de los mismos elementos que la intitulación, excepción hecha del pronombre personal. El dativo «a uos» o el ablativo «con uos» 0 «conuusco» ${ }^{274}$ suele dar comienzo a la misma.

Como la intitulación, la dirección podrá ser simple, conjunta o colectiva y comparecer el destinatario por sí mismo o/y mediante representante, en cuyo caso se ampliará la fórmula con los aditamentos referidos en aquélla. Evoluciona de igual modo que la intitulación a la cual, para este efecto, remitimos al objeto de evitar reiteraciones.

La disposición es la fórmula que ofrece mayor variedad pues está en consonancia con el acto o hecho documentado y, a la postre, será la que nos permitirá definir los tipos. Los verbos o locuciones que la concretan e, incluso, anuncian son los que, a continuación, relacionamos ${ }^{275}$ :

*Para el poder para pleitos:

-Fazemos nuestro procurador ${ }^{276} \ldots$,

-Fago mío personero ${ }^{277} \ldots$,

*Para la compraventa:

-Uendo/emos e robro/amos ${ }^{278}, \ldots$,

${ }^{271}$ A. BARrios García, Catedral de Avila, doc. 167 (1296), donación.

${ }^{272}$ L.M. VILlar GARCÍA, Catedral de Segovia, doc. 239 (1296) testamento.

${ }^{273}$ M. MaÑueco VIllalobos y J. ZURITA NiETo, Colegial de Valladolid, doc. LXXVII, 1281, pp. 11-14, donación.

${ }^{274}$ Diccionario de autoridades, A-C, Madrid, 1979, p. 582: "adv. Lo mismo que con vos o con vosotros...".

${ }^{275}$ Recogemos bajo una misma mención los ejemplares concretados en singular y plural.

${ }^{276}$ M. MaÑueCo Villalobos y J. ZuRITA NiETo, Colegial de Valladolid, poder inserto en doc. CXXI (1293).

${ }^{277}$ Ibidem, poder inserto en doc. CXXI (1293).

${ }^{278}$ J.M. LIZOAÍN GARRIDO, Huelgas, docs. 503 (1258), 514 (1260), 515 (1260) y 522 (1262). F.J. Pereda Llanera, Catedral de Burgos, docs. 130 (1275) y 290 (1293). 
-Uendo/emos ${ }^{279} \ldots$,

-Otorgo que vendo ${ }^{280} \ldots$,

-Otorgo/amos e connosco/emos que vendo/emos ${ }^{281} \ldots$,

*Para la puesta en posesión de inmueble:

$$
- \text { Meto }^{282} \ldots \text {, }
$$

*Para la permuta:

-Fago/zemos cam[b]io ${ }^{283} \ldots$,

-Damos en cam[b]io ${ }^{284} \ldots$,

-Dó...por ${ }^{285} \ldots$,

*Para la donación ${ }^{286}$.

-Dó e otorgo ${ }^{287} \ldots$,

$-\mathrm{Dó}^{288} \ldots$,

-Dó en don $^{289} \ldots$,

${ }^{279}$ J.M. LizoAín GARRIDO, Huelgas, docs. 508 (1259), 517 (1260) y 518 (1260). F.J. PEREDA Llanera, Catedral de Burgos, docs. 32 (1257), 40 (1258), 41 (1258), 64 (1263), 86 (1267), 100 (1270), 164 (1280), 189 (1284), 233 (1289), 305 (1295) y 324 (1299). L.M. VILLAR GARCIA, Catedral de Segovia, docs. 165 (1258), 180 (1267), 185 (1272), 187 (1273), 196 (1276), 203 (1279), 204 (1279) y 214 (1288). A. BARRIOS GARCÍA, Catedral de Avila, doc. 125 (1285). M. MAÑUECO VILlaloBOS y J. ZuRITA NIETO, Colegial de Valladolid, docs. LXV (1275), LXVI (1275), LXVIII (1276), LXXIII (1279), LXXV (1280), LXXIX (1283) y LXXX (1283).

${ }^{280}$ L.M. Villar GARCía, Catedral de Segovia, doc. 208 (1285) y 227 (1291).

${ }^{281}$ A. Barrios García, Catedral de Ávila, docs. 90 (1265), 123 (1285), 166 (1296), 130 (1285), 131 (1285), 132 (1286), 139 (1289), 151 (1291) y 161 (1294).

${ }^{282}$ F.J. Pereda Llanera, Catedral de Burgos, doc. 140 (1276).

${ }^{283}$ M. MaÑueco Villalobos y J. Zurita NiEto, Colegial de Valladolid, doc. LXII (1268). F.J. Pereda Llanera, Catedral de Burgos, docs. 133 (1276), 135 (1276).

${ }^{284}$ M. MAÑUeCo VILlalobos y J. ZuRITA NiETo, Colegial de Valladolid, docs. LXXIV (1280), LXXXIII (1285) y CVII (1289). A. BARRIOS GARCIA, Catedral de Avila, doc. 127 (1285).

${ }^{285}$ L.M. VILlar García, Catedral de Segovia, doc. 207 (1285).

${ }^{286}$ De todas las donaciones relacionadas sólo dos son remuneratorias por los servicios recibidos del donatario (A. BARRIOS GARCÍA, Catedral de Avila, doc. 160 (1294). M. MAÑUECO VILlALOBOS y J. ZURITA NIETO, Colegial de Valladolid, doc. XCI (1287). El resto son del tipo llamado "dotación de capellanía" (Vid. P. OsTOS-M.L. PARDO, Documentos y notarios de Sevilla, pp. 143-152).

${ }^{287}$ F.J. PeReda Llanera, Catedral de Burgos, doc. 143 (1277). M. MaÑueCo Villalobos y J. ZuRITA NIETO, Colegial de Valladolid, docs. LXXVII (1281) y XCI (1287).

${ }^{288}$ M. MaÑueCo VIllalobos y J. ZuRITA NiETo, Colegial de Valladolid, docs. LXXXII (1284) y CXXIII (1294). A. BARRIOS GARCÍA, Catedral de Avila, doc. 160 (1294).

${ }^{289}$ F.J. PEREDA Llanera, Catedral de Burgos, doc. 138 (1276). 
-Dó e offrezco ${ }^{290} \ldots$,

*Para la confirmación de donación:

-Otorgo e confirmo la donación ${ }^{291} \ldots$,

*Para la deuda ${ }^{292}$ :

- Deuo $^{293} \ldots$,

-Entramos fiadores e debdores...por dar ${ }^{294} \ldots$,

-Só fiador e debdor...por dar ${ }^{295} \ldots$,

- Connosco e otorgo que deuo dar ${ }^{296} \ldots$,

*Para la prenda:

-Empenno ${ }^{297} \ldots$,

*Para el pago:

—Otorgo que só pagado ${ }^{298} \ldots$,

*Para la constitución de censo:

- Damos...de fuero ${ }^{299} \ldots$,

*Para la transacción:

- Ponemos et fazemos tal pleyto et postura ${ }^{300} \ldots$,

-Fazemos tal abenençia ${ }^{301} \ldots$,

-Fazemos postura e abenencia e paramiento ${ }^{302} \ldots$,

${ }^{290}$ A. Barrios García, Catedral de Ávila, doc. 167 (1296).

${ }^{291}$ F.J. PEREDA Llanera, Catedral de Burgos, doc. 67 (1264).

${ }^{292}$ No podemos ofrecer el ejemplo de un reconocimiento de deuda vallisoletano por deterioro del ejemplar. No obstante, presenta fórmula anunciadora de la disposición en los siguientes términos: «venimos connosçudos et otorgamos et manifestamos en este pú...» Vid. M. MAÑUECO Villalobos y J. Zurita Nieto, Colegial de Valladolid, doc. LIX (1265).

${ }^{293}$ J.M. LIZOAín GARRIDO, Huelgas, doc. 516 (1260).

${ }^{294}$ F.J. PEREDA Llanera, Catedral de Burgos, docs. 101 (1272), 103 (1272) y 128 (1275).

${ }^{295}$ F.J. PEREDA Llanera, Catedral de Burgos, doc. 102 (1272) y 214 (1286).

${ }^{296}$ F.J. Pereda Llanera, Catedral de Burgos, doc. 345 (1300).

${ }^{297}$ F.J. PEREDA Llanera, Catedral de Burgos, doc. 111 (1274) y 277 (1292).

${ }^{298}$ L.M. Villar García, Catedral de Segovia, doc. 233 (1295).

${ }^{299}$ M. MañueCo Villalobos y J. ZuRITA Nieto, Colegial de Valladolid, doc. LXI (1268).

${ }^{300}$ M. MaÑueco Villalobos y J. ZuRita Nieto, Colegial de Valladolid, doc. LX (1266).

${ }^{301}$ A. Barrios García, Catedral de Ávila, doc. 140 (1289).

${ }^{302}$ F.J. PEREDA LlANERA, Catedral de Burgos, doc. 338 (1299). 
-Fazemos nuestra auinençia e nuestra compussiçión ${ }^{303} \ldots$,

* Para el compromiso en árbitros:

-Escoiemos et ordenamos et fazemos árbitros et difinidores et alabadores et comunes amigos ${ }^{304} \ldots$,

*Para el testamento:

-Fago este testamento ${ }^{305} \ldots$,

-Fago mi manda e mi diuisión ${ }^{306} \ldots$,

-Vltiman exprimens voluntatem ${ }^{307} \ldots$,

-Fago mío testamento ${ }^{308} \ldots$,

-Fago et ordeno mío testamento ${ }^{309} \ldots$,

to que...fago ${ }^{310} \ldots$,

-Esta es carta de la diuisión e postremera manda e testamen-

* Para la entrega y recepción de legado:

-Otorgamos que damos et desamparamos ${ }^{311} \ldots$,

- Connosçemos e otorgamos que reçebimos ${ }^{312} \ldots$,

- Só entregado et apoderado ${ }^{313} \ldots$

-Damos por $^{314} \ldots$,

En general, a medida que transcurre la segunda mitad del siglo, advertimos mayor precisión en los verbos o locuciones verbales usados para

${ }^{303}$ M. MaÑueco Villalobos y J. ZuRita Nieto, Colegial de Valladolid, doc. LVII (1263).

${ }^{304}$ M. MAÑUECo VILlalobos y J. ZuRITA NiETo, Colegial de Valladolid, compromiso inserto en doc. CXXI (1292).

${ }^{305}$ A. Barrios García, Catedral de Ávila, doc. 88 (1263).

${ }^{306}$ F.J. Pereda Llanera, Catedral de Burgos, doc 104 (1272), 154 (1278) y 264 (1291).

${ }^{307}$ F.J. PEREDA Llanera, Catedral de Burgos, doc 142 (1277).

${ }^{308}$ M. MaÑUeco Villalobos y J. ZuRita Nieto, Colegial de Valladolid, docs. LXXI (1278) y CII (1288).

${ }^{309}$ M. MAÑUECo Villalobos y J. ZuRITA NiETo, Colegial de Valladolid, doc. LXXII (1279). L.M. VILlar GarCía, Catedral de Segovia, doc. 239 (1296).

${ }^{310}$ F.J. PEREDA Llanera, Catedral de Burgos, doc. 238 (1290).

${ }^{311}$ L.M. Villar García, Catedral de Segovia, doc. 197 (1277).

${ }^{312}$ F.J. PEREDA Llanera, Catedral de Burgos, doc. 235 (1289).

${ }^{313}$ L.M. Villar García, Catedral de Segovia, doc. 226 (1291). (1299).

${ }^{314}$ M. MañueCo Villalobos y J. ZuRITA Nieto, Colegial de Valladolid, doc. CXXXII 
concretar la disposición. Incluso cabe señalar, especialmente en los documentos abulenses, el uso de aquella tautología verbal que, anunciando la disposición, alcanzaría tanto éxito en los documentos notariales de los siglos posteriores, a saber: «otorgo e conosco que».

Considerados desde el punto de vista de las cláusulas los documentos examinados acusan desde fines de la década del cincuenta un progresivo enriquecimiento al tiempo que se despojan o bien retroceden elementos tradicionales.

Significativo al respecto es la persistencia en Burgos de las tradicionales sanciones penales espirituales que no desaparecen con el cambio del siglo. Mientras, de Valladolid, Segovia y Ávila están ausentes en parangón a lo acontecido en otros territorios de los reinos de León y de Castilla, donde o éstas no figuran - caso de Sevilla ${ }^{315}$ y de Salamanca ${ }^{316}$ - o van abandonándose progresivamente $^{317}$.

De cualquier modo, dichas penas espirituales que, en el segundo cuarto del XIII, amenazaban al infractor, de ordinario, con la excomunión y la maldición cuando no, además, con la cólera divina, la de la Virgen y la de los Santos, así como con la suerte de Judas, se simplifican desde la segunda mitad de la centuria, llamando sobre el contraventor la ira divina y, excepcionalmente, la de la Virgen.

Tampoco desaparecen de los documentos burgaleses las sanciones penales temporales, previstas para el supuesto de incumplimiento de lo estipulado. Junto a la ira divina, la multa pecuniaria, pagadera al monarca, y la devolución doblada al adquirente del bien transmitido con, de ordinario, las mejoras introducidas son constantes en ejemplares que versan sobre transmisión de inmuebles ${ }^{318}$.

\footnotetext{
${ }^{315}$ Vid., al respecto, P. Ostos-M.L. PARDO, Documentos y notarios de Sevilla.

${ }^{316}$ En Salamanca, la presencia de tales cláusulas no va más allá de los años sesenta del siglo XIII, vid. J.L MARTín MARTín ET ALII, Op. cit.

${ }^{317}$ Caso de los documentos gallegos (Vid., al respecto, M. LuCAS ÁlVAREZ, El notariado en Galicia, p. 370.).

${ }^{318} \mathrm{Circunstancia}$ asimismo, evidente en Galicia (Vid. J. BONO HUERTA, Historia del Derecho, I. 2, p. 32 y M. LUCAS ÁLVAREZ, El notariado en Galicia, p. 370) y, en lo que respecta a la pena del doble, en Salamanca si bien la multa pagadera al rey desaparece a fines de la década de los sesenta (Vid. J.L MARTín MARTín, Op. cit.).
} 
Valgan como botón de muestra las cláusulas que, de los referidos tipos, consignan dos compraventas burgalesas, separadas por algo más de medio siglo:

\footnotetext{
$\mathrm{Si}$ quis hanc nostram cartam uendicionem et roborationem infringere uoluerit, primis, iram Dei habeat et sedeat excommunicato et cum Iudas in inferno condempnato et in coto regi terre mille aureos persoluat et uobis, $\mathrm{N}$ (i.e. comprador)..., ista hereditate supra dicta dupplata uel meliorata in simili tali loco $^{319}$.

Et qualquier que esta uenta quisiere temptar o quebrantar aya la yra de Dios o de Sancta María e peche en coto al rey de la tierra este precio sobredicho doblado e a uos, $\mathrm{N}$ (i.e. comprador)..., esta uenta sea doblada e meiorada en otro a tal semeiable logar ${ }^{320}$.
}

Empero, a dichas cláusulas, cuya pervivencia en Burgos explica el peso de la tradición, se suman o, como es el caso de Valladolid, Segovia y Ávila, substituyen otras sanciones más prácticas y acordes con las prescripciones y usos romanistas. Cierto es que el empleo que se hace de las mismas dista aún de alcanzar la proliferación y extensión con que aparecen en documentos notariales de los siglos XIV y XV, mas sorprende la variedad de tipología e, incluso, para determinados tipos, la fijación temprana de su redacción.

En ello, pues, veremos utilizadas cláusulas de renuncia, de aceptaeión, de promesa, de obligación y de fianza. Las primeras, sin precedentes en la primera mitad del siglo XIII, son exiguas, salvando el supuesto de las renuncias.

Es el caso de la cláusula de aceptación, presente en un documento de prenda en Burgos y en algunos documentos de permuta, donación y testamento en Valladolid:

Et yo, don [Pero Fernández] sobredicho, recebí este heredamiento sobredicho a pennos de uos, Roy García, sobredicho mýo [cunnado], segund que sobredicho es por esta carta ${ }^{321}$.

${ }^{319}$ J.M. LIZOAíN GARRIDO, Huelgas, doc. 267 (1231), pp. 18-19, compraventa.

${ }^{320}$ F.J. Pereda Llanera, Catedral de Burgos, doc. 305 (1295).

${ }^{321}$ F.J. Pereda Llanera, Catedral de Burgos, doc. 111 (1274), pp. 158-159, prenda. 
Et yo, Garci Gil, otorgo este camio et lo he por firme et dó a uos, el cabildo sobredicho, las casas sobredichas en la manera que sobredicho $\mathrm{es}^{322}$.

Et yo, don Roy Díaz, abbat sobredicho, reçibo de uos, el abbat et el conuento sobredichos, esta casa sobredicha con las condiciones que escriptas son en esta carta... ${ }^{323}$.

Et nos, el dicho cabildo de la eglesia de Sancta María de Valladolit, lo otorgamos todo esto et lo auemos por firme... ${ }^{324}$.

Lo mismo ocurre con las cláusulas de promesa, simple o bajo la forma de juramento, cuya presencia puede considerarse anecdótica. De 1258 data la cláusula de promesa más antigua presente en una compraventa burgalesa para reforzar la obligación de los compradores de realizar dos aniversarios anuales en favor de los padres del vendedor como pago de parte del precio. Dos poderes, una compraventa, tres donaciones, un compromiso y un documento de recepción de legado, correspondientes a los años ochenta y noventa, constituyen los tipos documentales con representación de la misma:

Et nos, los sobredichos mayordomos, prometemos por todo el cabildo de cumplir, así cumo sobredicho es, todo a uos, don Marín Pérez, el alcalde, e a los que uinieren despos uos por siempre yamás ${ }^{325}$.

Et prometo de non venir yo nin otri por mí contra lo que en esta carta se contiene, en todo nin en parte dello ${ }^{326}$.

Et prometo por mí e por mis herederos de non venir contra esta donaçión ${ }^{327}$.

Et prometemos sollempnemientre por sollempne stipulación de estar al aluedrío dellos et a lo que ellos alabaren et dixieren o juzgaren o mandaren,

${ }^{322}$ M. Mañueco Villalobos y J. Zurita Nieto, Colegial de Valladolid, doc. CVII, 1289, pp. 187-188.

${ }^{323}$ M. Mañueco Villalobos y J. ZuRita Nieto, Colegial de Valladolid, doc. XCI, 1287 , pp. 105-108, donación.

${ }^{324}$ M. MañueCo Villalobos y J. ZURITA Nieto, Colegial de Valladolid, doc. LXXII, 1279, pp. 411-415, testamento.

${ }^{325}$ F.J. Pereda Llanera, Catedral de Burgos, doc. 40 (1258), pp. 58-59, compraventa.

${ }^{326}$ A. Barrios García, Catedral de Avila, doc. 166 (1296), pp. 159-161, compraventa.

${ }^{327}$ A. Barrios García, Catedral de Ávila, doc. 167 (1296), donación. 
en qualquier manera, et non uenir contra ello, de derecho nin de fecho, nin de contradezillo nin apellar a ningún juez mayor porque pueda seer emendado nin desatado lo que ellos fezieren o mandaren ${ }^{328}$.

Et prometemos et otorgamos de auer por firme quanto este procurador fiziere et razonare ${ }^{329}$.

Et prometo et otorgo de auer por firme quanto este personero o los personeros que él por mí en su lugar fiziere, fizieren o fiziere ${ }^{330}$.

Et prometemos de nos atener todo esto que sobredicho es et de nunca uenir contra ello en todos uuestros días ${ }^{331}$.

Et prometemos de nunca uenir contra él (i.e. testamento) por desfazerle nin menguarle por nos nin por otre en ninguna manera, en iuyzio nin fuera de iuyzio $^{332}$.

Por su parte, la cláusula de juramento está presente en una escritura de prenda burgalesa de 1274 y en una compraventa de Segovia de 1297. Incompleta, por deterioro, en la primera, se muestra en la última como la promesa de cumplir lo estipulado, tomando como testigo los Evangelios:

Et juro (mancha) que non uenga contra esto en ninguna manera ${ }^{333}$.

Et, para esto conplir, ... yuró sobre los Sanctos Evangelios, por sí et por sus herederos, de conplir... ${ }^{334}$.

${ }^{328}$ M. MAÑUeCo Villalobos y J. ZuRITA NiEto, Colegial de Valladolid, compromiso inserto en doc. CXXI (1292).

${ }^{329}$ M. MaÑueCo Villalobos y J. ZuRita NiEto, Colegial de Valladolid, poder inserto en doc. CXXI (1293), pp. 261-262.

${ }^{330}$ M. MAÑueco Villalobos y J. ZuRita Nieto, Colegial de Valladolid, poder inserto en doc. CXXI (1293), pp. 265-266.

${ }^{331}$ M. MaÑUeco VIllalobos y J. ZuRITA NiETo, Colegial de Valladolid, doc. XCI (1287), pp. 105-108, donación. legado.

${ }^{332}$ F.J. Pereda Llanera, Catedral de Burgos, doc. 235 (1289), pp. 302-303, recepción de

${ }^{333}$ F.J. Pereda Llanera, Catedral de Burgos, doc. 111 (1274), prenda.

${ }^{334}$ L.M. Villar GarCía, Catedral de Segovia, doc. 240 (1297), compraventa. 
Mientras, la cláusula de obligación general de persona y/o bienes, llamada a alcanzar tanto éxito en la generalidad de los documentos notariales de siglos posteriores, de manera aislada ${ }^{335}$, sólo la registra un documento de transacción burgalés y cinco vallisoletanos, dos de poder y uno de deuda, de transacción y de compromiso, respectivamente. La más antigua data de 1265 pero son los documentos de finales de los ochenta y de la década de los noventa los que hacen mayor uso de ella:

Et, a esto, obligamos todo quanto nos auemos de eglesia et de patrimonio et auer deuemos de oy en adelante, mueble et heredat... ${ }^{336}$.

Et obligamos a nos et a todos nuestros bienes, spirituales et temporales, pora complir quanto fuere juzgado ${ }^{337}$.

Et obligo a mí et a todos míos bienes pora complir quanto fuere juzgado en todos los pleytos sobredichos o en cada qual dellos ${ }^{338}$.

Et yo, Gonçal Yoanes, et yo, Sancha Marcos, su muger, los sobredichos, obligamos a nos et a todos nuestros bienes de atener et conplir todo esto que en esta carta dise, assí commo sobredicho $\mathrm{es}^{339}$.

Et para esto atener e cumplir, segunt dicho es, nos, Garçía Pérez et donna María Andrés, obligamos a nos e a todos nuestros bienes, muebles e raýzes, ganados e por ganar... ${ }^{340}$.

\footnotetext{
${ }^{335}$ Decimos de manera aislada por cuanto desde la década de los sesenta, en los documentos burgaleses, la presencia de la cláusula de obligación general de bienes es constante, respaldando la fianza de saneamiento en los documentos de enajenación de bienes, según prescripción de Espéculo.

${ }^{336}$ M. MAÑUECo Villalobos y J. ZuRITA Nieto, Colegial de Valladolid, doc. LIX (1265), pp. 343-345, deuda.

${ }^{337}$ M. MaÑueco Villalobos y J. ZuRita Nieto, Colegial de Valladolid, poder inserto en doc. CXXI (1293), pp. 261-262.

${ }^{338} \mathrm{M}$. MAÑueCo Villalobos y J. ZuRita NiETo, Colegial de Valladolid, poder inserto en doc. CXXI (1293), pp. 265-266.

${ }^{339}$ M. Mañueco Villalobos y J. Zurita Nieto, Colegial de Valladolid, doc. C (1288), pp. 147-149, transacción.

${ }^{340}$ F.J. Pereda LlanERA, Catedral de Burgos, doc. 338 (1299), transacción.
} 
Et obligamos todos nuestros bienes, quantos oy día auemos e auremos cabadelantre $^{341}$.

Las cláusulas de renuncia hacen, asimismo, su aparición en la segunda mitad del siglo XIII ${ }^{342}$, tempranamente, en Burgos y Valladolid, algo más tarde en Segovia y en Ávila.

Al respecto, ya en una compraventa burgalesa de 1262 encontramos, tras la fórmula de satisfacción por el precio pagado, la declaración de nulidad emitida por el vendedor de cualquier confesión contraria a lo recibido, con denominación expresa de renuncia desde 1270, cláusulas que en Sevilla aparecen por vez primera en 1272 y 1282 , respectivamente ${ }^{343}$. Se formulan como sigue:

\footnotetext{
...e só de todo bien pagada e entregada a toda mi voluntad de preçio e de robra, así que non finco dent ninguna cosa por pagar, et en atal manera que yo nin omme por mí non podamos dezir en ningún tiempo del mundo que yo non fu pagada nin entregada deste preçio nin desta robra nin que finco dent ninguna cosa por pagar; et, si lo dixiéremos, que non nos vala... ${ }^{344}$.

...Et renuncio que en ningún tiempo del mundo non pueda dezir yo nin otri por mí que non recebí de uos estos XX maravedís (i.e. precio), e, si lo dixiere, que me non uala ${ }^{345}$.
}

En 1267 aparecerá desarrollada y fijada integramente la renuncia especial a la exceptio non numeratae pecuniae o «defensión de la pecunia non

${ }^{341}$ M. MañueCo Villalobos y J. ZURITA Nieto, Colegial de Valladolid, compromiso inserto en doc. CXXI (1292), pp. 259-260.

${ }^{342}$ Excepción al respecto lo constituye el doc. 370 (J.M. LizoAín GARRIDO, Huelgas, pp. 159-161) de compraventa de las "casas" de San Cebrián otorgada por el abad de Rioseco en favor de determinados ciudadanos burgaleses. Redactado por Martinus Petri, escriuano del conceio de Burgos, recoge ya en 1246 la renuncia a la «exceptión de non pagado e de non numerado precio» y a «non ganar en algún tiempo contra uos o contra uuestros herederos carta de appostóligo o de sennor de tierra porque esta uendición sea desfecha o reuocada». Como señala J. BONO HUERTA, Historia del Derecho, I. 2, p. 32: "No desvirtúa las líneas de esta evolución el hecho de la pronta aparición de cláusulas romanistas en docs. aislados, explicable por la influencia erudita del propio notario interviniente (e incluso de los otorgantes)".

${ }^{343}$ P. OSTOS-M.L. PARDO, Documentos y notarios de Sevilla, p. 108.

${ }^{344}$ J.M. LIZOAÍN GARRIDO, Huelgas, doc. 522 (1262), pp. 359-361, compraventa.

${ }^{345}$ F.J. PEREDA Llanera, Catedral de Burgos, doc. 100 (1270), pp. 143-144. 
contada», en la terminología legal castellana ${ }^{346}$, con denominación en romance:

E renunçio a la ley que diz que los testigos deuen ver fazer paga de dineros o de otra cosa qualquiere que lo vala; e a la otra ley que diz que fasta dos annos es tenudo aquél que auía de fazer la paga de prouar que fue fecha si en la carta non se quitar desta ley e desta defensión nombradamente... ${ }^{347}$.

Mientras, una confirmación de donación, de igual procedencia, recoge en 1264 una redacción incipiente de la renuncia genera ${ }^{348}$ que adoptará forma definitiva en la década de los noventa:

E, sin todo esto, partímosnos de toda ayuda e de toda defensión que nos non podamos ayudar ${ }^{349}$.

Et renunçio a éstas e a todas las otras leyes, razones e defensiones que contra esta carta sean; que me non valan ${ }^{350}$

Asimismo, Valladolid nos ofrece un ejemplo temprano de introducción de las renuncias documentales. Un reconocimiento de deuda, datado en 1265, recoge la renuncia especial a los plazos citatorios de tres, nueve y treinta días, establecidos en Fuero Real ${ }^{351}$ que, para Sevilla, no se constata hasta 1284 en los documentos de obligación ${ }^{352}$ :

Et desde aquí renunçiamos en este público instrumento a todo plazo de tres et de nu[eue et de] treynta días et a todas ferias et a todo benefiçio del rey por razón de la hueste et a todo derecho de la eglesia e del sieglo, que nos

${ }^{346}$ Partida 5, 1, 9 y 3, 18, leyes 56, 61, 63-64 y 70.

${ }^{347}$ F.J. Pereda Llanera, Catedral de Burgos, doc. 86 (1267), pp. 126-127, compraventa.

${ }^{348}$ Presente en el formulario de compraventa de Partida 3, 18, 56 y 3, 18, 61, de permuta de Partida 3, 18, 66 y de préstamo de Partida 3, 18, 70.

${ }^{349}$ F.J. PEREDA Llanera, Catedral de Burgos, doc. 67 (1264), pp. 93-95, confirmación de donación.

${ }^{350}$ F.J. Pereda Llanera, Catedral de Burgos, doc. 277 (1292), pp. 348-349, prenda.

${ }^{351}$ Fuero Real 2, 3, 1, 4-5.

${ }^{352} \mathrm{Cfr}$. J. Bono HuerTa, Historia del Derecho, I. 2, p. 33, nota 5. 
conuiene agora o nos podrá [conuenir], porque la dicha paga et penas se puedan enbargar ${ }^{353}$.

Sin embargo, en Segovia y Ávila las renuncias documentales no constan hasta la década de los noventa. Insertan tanto la renuncia especial a la exceptio non numeratae como la general y, además, como nota singular, dos compraventas de Segovia la renuncia especial al fuero seglar y, consiguientemente, la cláusula de (promesa o de juramento de) sumisión del otorgante a la jurisdicción eclesiástica:

\footnotetext{
Et para esto conplir renunció al fuero seglar e yuró sobre los Sanctos Evangelios, por sí et por sus herederos, de conplir et de estar a juyzio et a mandamiento de Sancta Eglesia en esta razón ${ }^{354}$.

Et para esto renuncio al fuero seglar et oblígome a juisio et a mandamiento de Santa Eglesia... ${ }^{355}$.
}

De igual modo, una compraventa abulense de 1296 recoge la renuncia a la excepción del engaño ${ }^{356}$ :

\footnotetext{
...renunçio la ley que dize que, si el vendedor se toviere por engannado de la vendida, que fiziere que el comprador deve fasta tienpo çierto conplirle el derecho preçio o desffazer la vendida ${ }^{357}$.
}

Por contra, el empleo de la cláusula de fianza, esporádico para Burgos en la primera mitad del XIII, se generaliza en la segunda para asegurar tanto obligaciones de dar - en reconocimientos de deuda-como obligaciones de hacer. Entre estas últimas cobra singular relevancia la que refuerza la obligación de saneamiento ${ }^{358}$, presente en los documentos de prenda, permuta,

${ }^{353}$ M. MaÑueco Villalobos y J. Zurita Nieto, Colegial de Valladolid, doc. LIX (1265), pp. 343-345, deuda.

${ }^{354}$ L.M. Villar García, Catedral de Segovia, doc. 240 (1297), pp. 376-377.

${ }^{355}$ L.M. VIllar García, Catedral de Segovia, doc. 243 (1297), pp. 378-379.

${ }^{356}$ Fuero Real 3, 10, 5 y Partida 3, 18, 56 y 5, 5, 56.

${ }^{357}$ A. Barrios García, Catedral de Ávila, doc. 166 (1296), pp. 159-161.

${ }^{358}$ Regulada en Fuero Real 3, 10, 7, Espéculo 4, 12, leyes 35, 36 y 37, Partida 5, 5, leyes 32,33 y 35 y Partida 3, 18, 56. 
donación y, especialmente, de compraventa. En efecto, es en la compraventa, cualquiera que sea el lugar de procedencia, donde, de modo casi constante, desde mediados del XIII, la fianza garantiza la defensa del adquirente (redrar) $\mathrm{y}$, en consecuencia, la posesión pacífica del bien transmitido ante el riesgo de reivindicación o de privación (evicción de evincere) por tercero. Al margen de que el transmitente instituya como fiador a otra persona, los documentos examinados recogen la entrada, según tradición castellana ${ }^{359}$, del propio transmitente como fiador de saneamiento ${ }^{360}$. Si comparamos la fórmula utilizada en los documentos burgaleses durante la primera mitad del siglo XIII con la que registran los de la segunda, observamos un desarrollo mayor en estos últimos al precisar, de acuerdo con lo dispuesto ya en Espéculo $^{361}$, que la responsabilidad asumida queda respaldada con la totalidad de los bienes del fiador, circunstancia, asimismo, constatada para Galicia ${ }^{362}$ y Sevilla ${ }^{363}$ pero inadvertida en los documentos de Valladolid, Segovia y Ávila. Dos ejemplos ofrecemos, a continuación, que sancionan lo dicho:

Et, super hoc, ego, N..., qui uendo, só uos fiador e debdor de riedra de totum hominem deste solar superscripto ${ }^{364}$.

Et, demás, dó comigo por fiadores a Iohan Pérez, fijo de Domingo ${ }^{365}$ Yuánnez de la Vieia, e a Pero Sánchez, fijo de Yuan Pérez de la Calera, vecinos de Sant Cosme. Et nos, N... e N... e N..., los sobredichos, todos de mancomún e cada vno por todo, somos fiadores e debdores con quanto auemos e auremos cabadelante, muebles e raýçes, de ryedra de todo omme que esta uenta sobredicha contralle, toda o parte della, por qualquier raçón, e de la fazer sana en todo tiempo que mester sea ${ }^{366}$.

${ }^{359} \mathrm{Cfr}$. J. BONO HUERTA, La práctica notarial, pp. 502-503.

${ }^{360}$ Sobre la responsabilidad por evicción de inmuebles vid. R. FERNÁNDEZ ESPINAR, La compraventa en el Derecho medieval español, "Anuario de Historia del Derecho Español", XXV (Madrid, 1955), pp. 498-518.

${ }^{361}$ Espéculo 4, 12, 35 (compraventa) y 4, 12, 36 (permuta).

${ }^{362}$ M. LUCAS Álvarez, Documentos notariales y notarios, p. 235.

${ }^{363}$ P. OSTOS-M.L. PARDO, Documentos y notarios de Sevilla, p. 110.

${ }^{364}$ J.M. LIzOAÍN GARRIDO, Huelgas, doc. 265 (1231), p. 16, compraventa.

${ }^{365}$ Repetido: de Domingo.

${ }^{366}$ F.J. PEREDA Llanera, Catedral de Burgos, doc. 305 (1295), compraventa. 
A mayor abundamiento, para el supuesto de que el fiador/es, entre los que, según se ha indicado, se encuentra el propio transmitente, no quiera o no pueda proceder a la defensa y saneamiento, la fianza en cuestión va seguida, en Segovia y en Ávila, de indemnizaciones que comportan desde abonar al adquirente el precio doblado y/o las costas y perjuicios doblados derivados del juicio que hubiera motivado la evicción hasta el pago de una cantidad por días pasados sin «redrar e sanar», esta última pagadera (en Segovia) también a los jueces:

\footnotetext{
et, si redrar et sanar non quissiéssemos, que vos pechemos estos maravedís sobredichos doblados. Et por los moravedís et por el doble et por el redrar et sanar quantos días vos, $\mathrm{N}$ (i.e. comprador) ..., el sobredicho, o quien esta carta mostrasse diéssedes querella en los alcaldes, que tantos dos moravedís pechemos nos todos (i.e. vendedores) ... o quien nostra buena eredare a los alcaldes et tantos dos moravedís a vos, $\mathrm{N}$ (i.e. comprador)... fasta que redrássemos et sanássemos ... ${ }^{367}$.

e, quantos días passaren que non redráremos e non sanáremos, que vos pechemos un moravedí ... cada día en pena ${ }^{368}$.
}

Otras sanciones penales pecuniarias quedan previstas para el caso de que los actores incumplan sus obligaciones. Así, una cláusula de esta índole refuerza la promesa de estar a resultas de la sentencia emitida por los árbitros en el compromiso: una multa pagadera por la parte contraventora a la otra y la reparación de daños y perjuicios causados ${ }^{369}$. Por su parte, los reconocimientos de deuda recogen el abono de una multa dineraria pagadera por día de mora ${ }^{370} \mathrm{y}$, de ordinario, además una cláusula que faculta al acreedor para

${ }^{367}$ L.M. Villar García, Catedral de Segovia, doc. 187 (1273), pp. 296-297.

${ }^{368}$ A. Barrios García, Catedral de Ávila, doc. 123 (1285), pp. 111-112.

${ }^{369}$ M. MAÑUeCo Villalobos y J. ZURita Nieto, Colegial de Valladolid, doc. CXXI (1292), pp. 258-260.

${ }^{370}$ M. MAÑueco Villalobos y J. ZuRita NiETo, Colegial de Valladolid, doc. LIX (pp. $343-$ 345) y, asimismo, F.J. PEREDA LlanERA, Catedral de Burgos, docs. 101, (pp. 144-145), 102 (pp. 146-147), 103 (pp. 147-148), 128 (pp. 180-181) y 214 (pp. 278-279). 
tomar los bienes del deudor, venderlos o empeñarlos y cobrarse con el monto de la operación el débito ${ }^{371}$ :

E, sy a estos plazos non uos diere estos marauedís, que de los plazos adelante que uos peche cadal día ... moravedís por pena, por qualquier de los plazos que falezca. E, aún, sobresto douos poder que me podades prendar de uuestra auttoridat todo quanto me fallredes (sic), moble e raýz, uos o omme o ommes por uos, sin alcallde e sin merino e sin fuero e sin calonna ninguna, e uenderlo ho enpennarlo a uuestro pro e a mío danno e entregaruos de todos quantos maravedís uos yo ouiese a dar por esta razón e de la pena; e que seades creído por uuestra simple palaura, sin iura e sin testigo ${ }^{372}$.

Similar solución se prevé en una prenda para el supuesto de impago en el plazo estipulado, pues se faculta al acreedor para proceder, junto con los demás herederos, a la partición de las casas empeñadas y, hecha ésta, vender la parte correspondiente al deudor y cobrarse del precio el montante del débito así como los daños y menoscabos:

Et, si al dicho plazo non uos pagase los dichos maravedís, douos poder que uos, por uuestra auctoridat, sin alcalde e sin merino, partades las dichas casas (i.e. empeñadas) con los otros herederos e que vendades toda la parte e el derecho que yo, Iohán García, he en las casas sobredichas, o darlas a vender a corredores a uuestra pro e a mío danno; e que uos entreguedes por uos mismo de todos los maravedís sobredichos, con las costas e dannos e menoscabos que recibierdes por esta razón, e que me dedes lo que sobrare... ${ }^{373}$.

Pero, al margen de las cláusulas de sanción, los documentos de la segunda mitad del siglo XIII, especialmente desde la década de los setenta,

\footnotetext{
${ }^{371}$ Fuero Real 3, 20, 2: «Qui por debda que deuiere a plazo metiere sobre sí tal pena que, si non pagare al plazo, que aquél a qui deue la debda pueda tomar sus bienes doquier que los falle e uender e que sea creýdo sobre la uendida por su palabra lanna, tal pleyto como éste uala; et, si por sí fazer non lo quisiere o non pudiere, aya derecho por los alcaldes, e por esto non pierda ninguna cosa de so derecho de como fue puesto entrellos». Cfr. J. BONO HUERTA, La práctica notarial, p. 505.

${ }^{372}$ M. Mañueco Villalobos y J. Zurita Nieto, Colegial de Valladolid, doc. LIX (1265), pp. 343-345, y, asimismo, F.J. PEREDA LLANERA, Catedral de Burgos, docs. 101 (1272), pp. 144-145, 102 (1272), pp. 146-147, y 103 (1272), pp. 147-148.

${ }^{373}$ F.J. Pereda Llanera, Catedral de Burgos, doc. 277 (1292), pp. 348-349, prenda.
} 
suelen incorporar la cláusula de corroboración ${ }^{374}$, casi ausente para Burgos en los ejemplares de la primera mitad. Conjugando los tradicionales deseos de firmeza y de prueba, recoge la expresión del ruego y/o mandato que determina las actuaciones del notario (factura del documento o mandato de hacerlo y signado) y, de ordinario, de los testigos inscritos al pie del documento. Cuando éste va provisto de sello o se trata de una carta partida, consigna también titularidad y, en casos, modo de aposición, para el primero, así como el número de ejemplares mandados expedir, para la última:

Et, porque esto sea más firme et non venga en dubda, nos, las partes sobredichas, mandamos a Sancho Iohannes, escrivano público, que ficiese esta carta et pusiese en ella su signo en testimonio ${ }^{375}$.

Et, porque esto sea firme e estable e non uenga en dubda, amas las partes rogamos a Iohan Pérez, escriuano público de Burgos, fazer esta carta e a los ommes bonos que son escriptos en fin della que sean testigos ${ }^{376}$.

Et, porque esto sea firme et non venga en dubda, rogamos a Domingo Blasco, conpannero et notario público de la eglesia de Segovia, que fiziese esta carta et a estos ommes bonos que son desto testigos ${ }^{377}$.

E, porque esto sea firme e non venga en dubda, ruego a vos, Johán Pérez, que la registedes e dedes ende al dicho don Yagüe $\mathrm{vn}^{378}$ estumento (sic) signado con vuestro signo ${ }^{379}$.

Et, porque esto sea firme e non venga en dubda, nos, el dicho cabildo e donna Gometiça, rogamos a Martín Yuannes, escrivano público en Ávila por Alffonso Royz, escrivano público por el rey en Ávila, que fiziese ende dos

\footnotetext{
${ }^{375}$ L.M. Villar GarCía, Catedral de Segovia, doc. 187 (1273), pp. 296-298, compraventa. legado.

${ }^{376}$ F.J. Pereda Llanera, Catedral de Burgos, doc. 235 (1289), pp. 302-303, recepción de

${ }^{377}$ L.M. Villar García, Catedral de Segovia, doc. 234 (1295), pp. 366-367, compraventa.

${ }^{378}$ AHN, Sección Clero, "Ávila. Catedral. Pergaminos", carpeta 22, no ${ }^{\circ}$ 5. Cfr. A. BARRIoS García, Catedral de Avila, doc. 131, p. 117.

${ }^{379}$ A. Barrios García, Catedral de Ávila, doc. 131 (1285), pp. 116-117, compraventa.
} 505-506.

${ }^{374}$ Llamada, también, de "mayor firmeza", cfr. J. BONO HUERTA, La práctica notarial, pp. 
públicos instrumentos ante estos testigos, llamados e rogados, que estavan hý presentes ${ }^{380}$.

Et, porque esto non venga en dubda, mando fazer esta carta a Pero Martínez, escriuano público del conceio de Valladolit, et ruego a las pesquisas de yuso escriptas que lo firmen, si mester fuere ${ }^{381}$.

Et, porque esto sea firme et non venga en dubda, yo, Gonçal Yuanes, et yo, Diego Royz, (i.e. vendedor y fiador) los sobredichos, mandamos a Bartolomé Domínguez, escriuano público del conçeio de Valladolit por Marchos Pérez, que ficiesse esta carta et rogamos a las pesquisas en ella escriptas que lo firmen, si mester fuere ${ }^{382}$.

Et, porque esto non venga en dubda, mandemos a Martín Velasco, escriuano sobredicho, que faga de tod esto dos cartas públicas partidas por a. b. c. et, por más firmidumbre, mandemos poner nuestro seello en cada una destas cartas en testimonio ${ }^{383}$.

La data se sitúa al pie del documento previo a la lista de testigos. El incipit "Facta carta» hasta fines de la década de los cincuenta alterna, posteriormente, con «Fecha fue[es] esta carta», «Fecha la carta» 0 «Esta carta fue fecha», imponiéndose las formas castellanas, en Burgos, desde la década de los noventa. Por contra, el uso del latín es excepcional en Valladolid ${ }^{84}, \mathrm{y}$ no aparece en los incipit de Segovia y Ávila.

La data tópica, como mención del concejo donde fue «fecha» la carta, comienza a ser consignada, aunque no de modo sistemático, en Burgos desde 1257, acompañada o sustituida por la reseña del lugar en éste donde se confeccionó aquélla. En Valladolid, Segovia y Ávila la data tópica, como mención del concejo donde se elaboró el documento, es excepcional. Sólo un documento abulense la reseña ${ }^{385}$ y lo mismo ocurre con la indicación del lugar

\footnotetext{
${ }^{380}$ A. Barrios García, Catedral de Avila, doc. 140 (1289), pp. 124-125, transacción.

${ }^{381}$ M. MaÑueCo Villalobos y J. ZuRita NiEto, Colegial de Valladolid, doc. LXV (1275), pp. 384-385, compraventa.

${ }^{382}$ M. Mañueco Villalobos y J. ZuRITA NiETo, Colegial de Valladolid, doc. LXXIII (1279), p. 421, compraventa.

${ }^{383}$ M. MaÑueco Villalobos y J. ZuRITA Nieto, Colegial de Valladolid, doc. LXXVII (1281), pp. 11-14, donación.

${ }^{384}$ M. MAÑUeCo Villalobos y J. Zurita NiETo, Colegial de Valladolid, doc. LXII (1268).

${ }^{385}$ A. Barrios García, Catedral de Ávila, doc. 167 (1296).
} 
específico, tanto en Ávila ${ }^{386}$ como en Valladolid ${ }^{387}$, aunque tal mención en Segovia resulta frecuente.

La data crónica que, hasta 1257 en Burgos, expresaba, mayoritariamente, tan sólo mes y año y, en mucha menor proporción, el día del mes por el sistema de los días andados y por andar y, de manera excepcional, la fiesta litúrgica y el sistema de calendación romana se consigna de modo sistemático desde esa fecha.

A partir de 1257, en Burgos, el sistema de los días andados y por andar para expresar el día del mes alterna con el sistema directo que terminará por imponerse desde los comienzos del setenta, mientras su consolidación en Valladolid $^{388}$, Segovia ${ }^{389}$ y Ávila ${ }^{390}$ es, ligeramente, más temprana. También a fines de los cincuenta se introduce la mención al día de la semana que no quedará como elemento fijo, en Burgos, hasta el noventa, mientras en Valladolid, Segovia y Ávila ${ }^{391}$ viene a ser un elemento constante desde la implantación del notariado.

Para la expresión del año se acude, de ordinario, al sistema de la era hispánica. Hasta fines de los setenta éste se acompaña, en Burgos, de la expresión por el sistema de la era cristiana, bajo la forma Anno Domini, quedando la era hispánica como única a partir de ese momento. Eventualmente veremos documentos en Valladolid ${ }^{392}$ y en Segovia ${ }^{393}$ datados por el sistema de la era cristiana como cómputo único.

\footnotetext{
${ }^{386}$ Ibidem.

${ }^{387}$ M. MaÑueco Villalobos y J. ZuRITA Nieto, Colegial de Valladolid, docs. LX, CVII y CXXIX.

${ }^{388}$ Desde 1266 se impone el sistema directo para la expresión del día de la semana en Valladolid, con determinadas excepciones, así M. MAÑUECO VILlalobos y J. ZURITA NiETO, Colegial de Valladolid, docs. LXI (1268) y LXXIV (1280) en los cuales se usa el sistema de los días andados y por andar.

${ }^{389}$ El año 1267 marca en Segovia el comienzo de la expresión del día del mes por el sistema directo, al que se suma la indicación de la fiesta litúrgica en el doc. 214 (L.M. VILLAR GARCÍA, Catedral de Segovia).

${ }^{390}$ En Ávila la expresión directa del día del mes arranca, sin interrupción, desde 1263.

${ }^{391}$ Sólo hasta 1278 , momento a partir del cual desaparece toda indicación al día de la semana.

${ }^{392}$ M. MaÑueco Villalobos y J. Zurita Nieto, Colegial de Valladolid, doc. LXI (1268).

${ }^{393} \mathrm{Al}$ margen de las compraventas redactadas en forma objetiva, la expresión del año por el sistema de la era cristiana y el estilo de la Encarnación, sólo la consignan, en la segunda mitad del siglo XIII, los ejemplares siguientes: L.M. VILLAR GARCía, Catedral de Segovia, docs. 234 (1295) y 239 (1296).
} 
La data personal es elemento casi constante en Burgos hasta 1270, si bien a partir de 1257 desaparecen de la misma los nombres del merino, del juez y del sayón. Aunque decrece considerablemente su uso desde mediados de la década de los ochenta, todavía se conserva alguna presencia esporádica en los noventa. Por contra, la data personal está completamente ausente, al igual que en Sevilla, de los ejemplares vallisoletanos, segovianos y abulenses.

En suma, con relación a la data merece ser consignado:

1. el enriquecimiento de los elementos integrantes de la data desde fines de los cincuenta con la adición de los días del mes y de la semana, para la data crónica, y de la data tópica como mención del concejo o/y del lugar concreto en éste donde se confeccionó el documento.

2. el retroceso o/y desaparición de elementos tradicionales lo que acontece en los años setenta:

2.1. retroceso de la expresión del día del mes por el sistema de los días andados y por andar en beneficio del sistema directo.

2.2. acelerada desaparición de la expresión del año por el sistema de la era cristiana en beneficio de la expresión única por la era hispánica (en Burgos).

2.3. desaparición de la data personal (en Burgos).

Como curiosidad cabe señalar la presencia en un documento de Valladolid de dos datas crónicas distintas, correspondientes, una, al otorgamiento de la nota por los donantes y, otra, a la del donatario ${ }^{394}$.

A medida que el notariado se afianza, la fórmula de suscripción notarial, según se observa en los modelos incorporados, va sumando elementos: nombre del notario, título (desde 1263 es casi constante), indicación de la autoridad que le ha provisto de aquél (en casos), incardinación y carácter que reviste su actuación en el proceso de elaboración del mismo (presencia al otorgamiento, factura/mandato de escribirlo y signado). Reseña, además, con frecuencia, el ruego/mandato de las partes para hacerlo o mandarlo hacer y menciona la aposición del signo o señal, expresamente aludida en Valladolid desde 1255, en Burgos desde 1257, en Segovia desde

${ }^{394}$ M. Mañueco Villalobos y J. Zurita Nieto, Colegial de Valladolid, doc. XCI (1287). 
1258 y en Ávila desde 1263, con carácter constante, desde 1263 , como citan algunos notarios burgaleses, "assí commo manda nuestro sennor, el rey ${ }^{395}$.

Consecuentemente, la escueta suscripción del scriptor se ha transformado, cobrando la amplitud necesaria para dar cabida a los elementos que denotan la cualificación y nueva responsabilidad del redactor: el notario público, la única persona legalmente autorizada para proporcionar fe pública o credibilidad a los documentos "privados". Un ejemplo del modo de suscribir uno y otro servirá para sancionar lo dicho:

Ferdinandus, scripsit ${ }^{396}$.

Et yo, Iohán Pérez, escriuano público de Burgos, que fu a esto presente e (signo) escriuí esta carta e fiz en ella mío signo en testimonio ${ }^{397}$

\subsubsection{Actas}

Sólo cuatro ejemplares se ajustan a esta última estructura y son de fechas tardías pues el más antiguo data de 1272. Sus contenido y procedencia son los siguientes: dos compraventas de Segovia ${ }^{398}$ y dos actas, una de intima ${ }^{399}$ y otra de atestación ${ }^{400}$, burgalesas. Las actas no constituyen novedad para esta época en la Corona castellano-leonesa, según práctica constatada, ya en la primera mitad del XIII, en Galicia ${ }^{401}$ y León ${ }^{402}$ y, para la segunda, en

${ }^{395}$ F.J. Pereda Llanera, Catedral de Burgos, doc. 86 (1267), 104 (1272), 133 (1276), 142 (1277), 238 (1290), 297 (1293), 316 (1296), 324 (1299), 355 (1301). Expresión que, según J. BONO HUERTA, La práctica notarial, pp. 495-496, constituye una clara alusión a Espéculo 4, 12, 35.

${ }^{396}$ J.M. LIZOAín GARRIDO, Huelgas, doc. 493 (1256), pp. 320-321, compraventa.

${ }^{397}$ F.J. Pereda Llanera, Catedral de Burgos, doc. 305 (1295), compraventa.

${ }^{398}$ L.M. Villar García, Catedral de Segovia, docs. 186 (1272) y 240 (1297).

${ }^{399}$ F.J. Pereda Llanera, Catedral de Burgos, doc. 316 (1296).

${ }^{400}$ F.J. Pereda Llanera, Catedral de Burgos, doc. 318 (1296).

${ }^{401}$ M. LUCAS ÁlVAREZ, Documentos notariales y notarios, p. 235 y, del mismo autor, El notariado en Galicia, p. 370. En este último manifiesta: "En el siglo XIII se cambia frecuentemente esta formulación con la utilización frecuente del sistema llamado de "Acta», comenzando por la fecha...".

${ }^{402}$ J.A. MARTÍN FUERTES, Los notarios en León, p. 602. 
Sevilla ${ }^{403}$. No obstante, conviene llamar la atención sobre el empleo de la misma en las compraventas para fechas tan tempranas ${ }^{404}$ pues lo habitual es que el molde-acta se reserve, en la documentación notarial por "facilidad de redacción" hasta época moderna, para los documentos que consignan "actuaciones complejas" o bien para negocios que requieren la intervención judicial en su otorgamiento ${ }^{405}$, amén de ser la forma adoptada por los llamados "traslados-acta" ${ }^{406}$. De hecho, respondiendo a este esquema, tales documentos aparecen también en Burgos y, para iguales fechas, en Sevilla ${ }^{407}$. Habría resultado interesante conocer los contenidos específicos de "los documentos que comienzan por la fecha" de Galicia y de León pero los autores que se ocupan de la materia omiten toda indicación del asunto ${ }^{408}$. Por otra parte, Pilar Ostos Salcedo al estudiar la escribanía capitular burgalesa hace notar el uso de ambas formas de redacción sin distinción de asunto, si bien manifiesta la utilización para la confirmación de prior de la forma objetiva en exclusiva ${ }^{409}$.

En cualquier caso, la invocación verbal al nombre de Dios, en las compraventas, y la notificación universal, bajo la expresión "Sepan quantos esta carta vieren", en las actas de intima y atestación, da comienzo al tenor de las actas y no directamente la fecha ${ }^{410}$. Tras ellas, la data crónica $^{411}$, sin incipit alguno, reseña año, -por el sistema de la era cristiana en los ejemplares segovianos y de la era hispánica en los burgaleses-, día del mes

${ }^{403}$ P. OSTOS-M.L. PARDO, Documentos y notarios de Sevilla, p. 191.

${ }^{404}$ J. BONO HUERTA, Breve introducción, p. 60: "paralelamente a la redacción subjetiva, aparece en la segunda mitad del siglo XVI en Castilla la redacción objetiva..."

${ }^{405}$ Vid. J. BONO HuERTA, Breve introducción, p. 59.

${ }^{406}$ A.C. Floriano CUMBreÑo, Op. cit., pp. 233-236.

${ }^{407}$ P. OSTOS; M.L. PARDO, Documentos y notarios de Sevilla, p. 191, los localizan en tomas de posesión y traslados de mandas o legados.

${ }^{408}$ Sin embargo, el término "dispositivo" empleado por M. Lucas parece que incide en la aplicación del esquema de los documentos que comienzan por la fecha a tipos no narrativos ni descriptivos. Vid. M. LuCAS ÁlvarEZ, Documentos notariales y notarios, p. 235.

${ }^{409} \mathrm{P}$. OSTOS SALCEDO, Documentos y escribanía del cabildo catedralicio de Burgos (siglo XIII), "Espacio, Tiempo y Forma", Serie III, Historia Medieval, 7 (Madrid, 1994), p. 175.

${ }^{410}$ Como parece que ocurre en Galicia y León.

${ }^{411}$ Sólo en un documento burgalés la fórmula de intervención notario-testifical precede a la expresión de la data, mientras lo habitual es que aquélla la postceda, F.J. PEREDA LLANERA, Catedral de Burgos, doc. 318 (1296). 
por el sistema directo y, de ordinario, día de la semana ${ }^{412}$. Mediante la fórmula de intervención notario-testifical el escribano público asevera su presencia y la de los testigos en el acto o asunto que se dispone a narrar:

En presencia de mí, N .., notario público de la eglesia de Segovia por auctoridat de nostro sennor el obispo, et ante los testigos de yuso escriptos ${ }^{413}$.

ante ... los ommes buenos que son escriptos por testigos en fin desta carta e ante mí, N..., escriuano público de Burgos ${ }^{414}$.

La fórmula de comparecencia $a^{415}$, por su parte y sin los enlaces habituales en siglos posteriores ${ }^{416}$, recoge, según el caso, las señas de identidad del vendedor o el requirente.

El desarrollo posterior está en función de la actuación o asunto consignado. En las compraventas, como en las redactadas en forma subjetiva, recoge la disposición con la dirección subsumida, reseñando ésta la identificación del comprador para continuar con las circunstancias del negocio, a saber: determinación del inmueble y del precio, y confesión de su recibo. Las cláusulas de sanción (obligación o fianza de saneamiento, penas temporales por incumplimiento, promesa o juramento de cumplir...), la lista de testigos, la data tópica y remisión a la crónica y la suscripción notarial cierran el tenor de estos documentos.

En las actas de atestación e intima a la narración del hecho constatado o de la intimación realizada postcede la fórmula de solicitud o mandato de expedición del testimonio pertinente (carta pública) para terminar con la data tópica ${ }^{417}$ y remisión a la crónica, la lista de testigos y la suscripción notarial.

${ }^{412}$ No lo consigna el doc. 240 (L.M. VILlar GarCía, Catedral de Segovia).

${ }^{413}$ L.M. Villar García, Catedral de Segovia, docs. 186 y 240.

${ }^{414}$ F.J. Pereda Llanera, Catedral de Burgos, docs. 316 (1296) y 318 (1296).

${ }^{415}$ Esta fórmula falta en el acta de atestación si bien de la fórmula de solicitud de expedición es fácil deducir quien realiza la comparecencia ante el notario, el obispo.

${ }^{416}$ Nos referimos al «en testimonio paresçió». Vid. M.D. RoJAS VACA, Op. cit., pp. 92-99.

${ }^{417}$ No consigna data tópica alguna el acta de atestación (F.J. PEREDA LLANERA, Catedral de Burgos, doc. 318). 


\section{TIPOLOGÍA DOCUMENTAL}

El criterio de la forma de redacción, subjetiva u objetiva, es el más amplio y genérico y, como tal, el primero que habrá de barajarse al abordar un estudio tipológico de la documentación notarial. Criterio formal y, por ende, diplomático por cuanto repercute en la estructura de los documentos, esto es, en el orden y distribución de sus fórmulas, nos permite distinguir entre cartas y actas, redactadas en forma subjetiva y objetiva, respectivamente.

A partir de aquí, una tipología específica vendrá determinada por el acto o hecho concreto que el documento consigna ${ }^{418}$ y que, en un momento posterior, podremos ordenar agrupando los tipos según el criterio institucional sugerido por José Bono Huerta en una de sus publicaciones ${ }^{419}$.

Abierta a ulteriores estudios, la tipología que proponemos para la documentación notarial de Castilla la Vieja examinada, en la segunda mitad del siglo XIII, es la siguiente:

1. Cartas (redacción subjetiva)

1.1. Documentos relativos a la persona

1.1.1. Sobre la representación

1.1.1.1. Poder

1.2. Documentos relativos a los bienes

1.2.1. Sobre su transferencia y locación

1.2.1.1. Compraventa

1.2.1.2. Puesta en posesión

1.2.1.3. Permuta

1.2.1.4. Prenda

1.2.1.5. Donación

1.2.1.6. Confirmación de donación

\footnotetext{
${ }^{418}$ Cfr. C. Álvarez MÁrquez y P. OSTOS SAlCedo, Documentación señorial catalana: criterios para su clasificación (años 1187-1347), "Señorío y feudalismo en la Península Ibérica", III, Zaragoza, 1993, pp. 47-48, refieren que los criterios "definitorios de tipos en la documentación otorgada por particulares" son "el negocio jurídico y la naturaleza de disposición de voluntad".

${ }^{419}$ J. BONO HUERTA, Los archivos notariales, Sevilla, 1985, pp. 31-41.
} 
1.2.2. Sobre el crédito, real o personal

1.2.2.1. Censo

1.2.2.2. Deuda

1.2.2.3. Pago

1.2.2.4. Compromiso en árbitros

1.2.2.5. Transacción

1.3. Documentos relativos a testamentos, liberalidades mortis causa $y$ sucesión hereditaria

1.3.1. Testamento

1.3.2. Entrega o recepción de legado

\section{Actas (redacción objetiva)}

2.1. Documentos relativos a los bienes

2.1.1. Sobre su transferencia y locación

2.1.1.2. Compraventa

2.2. Otras actas:

2.2.1. Intimación

2.2.2. Atestación

\section{RÉSUMÉ}

On étude l'institution notariale et le document notarial à Castille pendant le XIII siècle. Faite une selection, l'appui de la proposition, on constitue avec les documents des collections diplomatiques éditées, faites d'après les archives ecclésiastiques de Burgos, Valladolid, Ségovie et Avila. Tellement, on prétend faire voir le comment et le porquoi de l'implantation du notariat public à Castille, on analyse l'action d'instruction des documents résultants des notaires et on étude sa forme. On finit avec l'élaboration d'une esquisse de typologie documentaire du matériel examiné.

\section{SUMMARY}

This work investigates the role of the notary institution and the documents issued in Castilla la Vieja during the $13^{\text {th }}$ century. The material examined comes principally from the collections of edited diplomatic documents coming from ecclesiastical archives in Burgos, Valladolid, Segovia and Ávila. In this study, we try to show how and when the public notary 
was instituted in the region, analysing the form of documents and the process by which they were issued and concluding with a typological outline of the documents and material employed.

\section{PALABRAS CLAVE}

Diplomática notarial.- Siglo XIII.- Castilla.

\section{KEYWORDS}

Notarial diplomatics.- 13th Century.- Castile. 


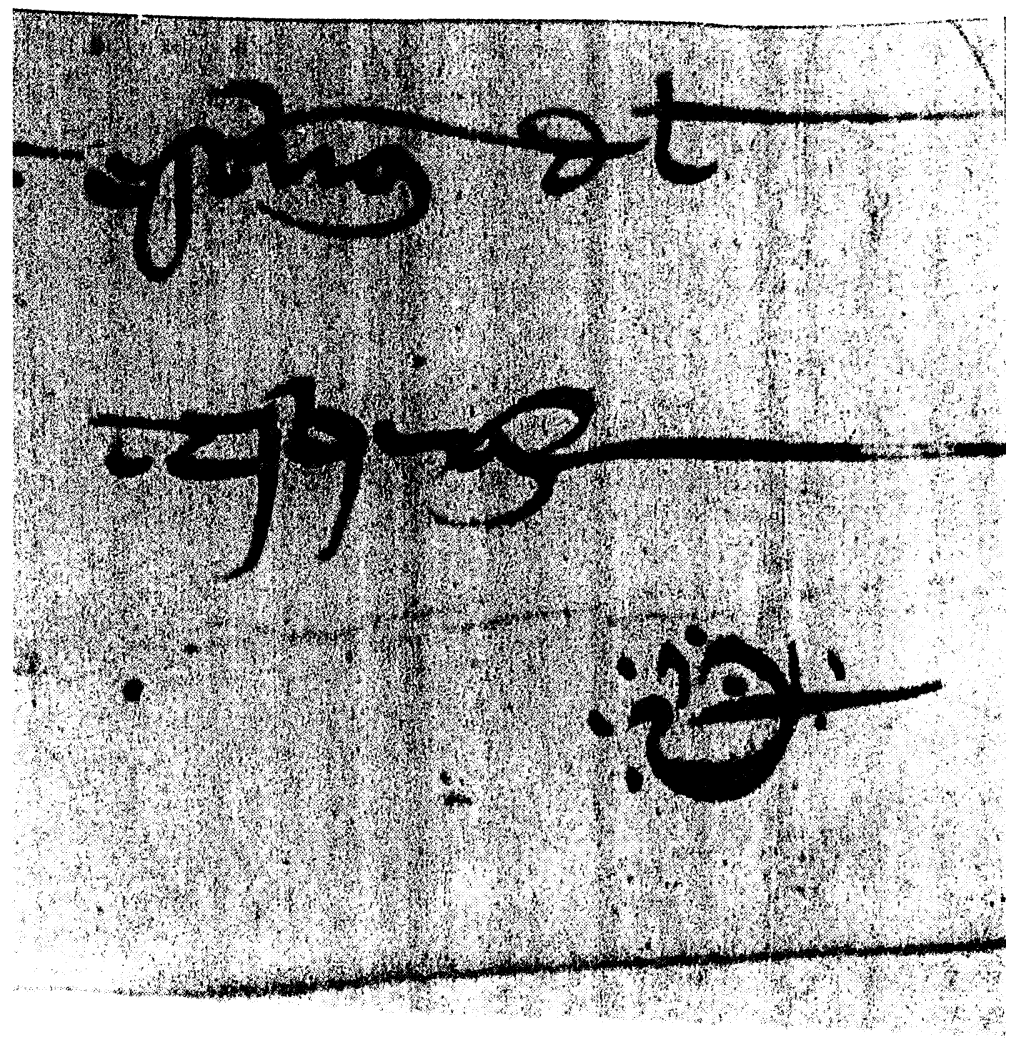

Fig.- 1. 


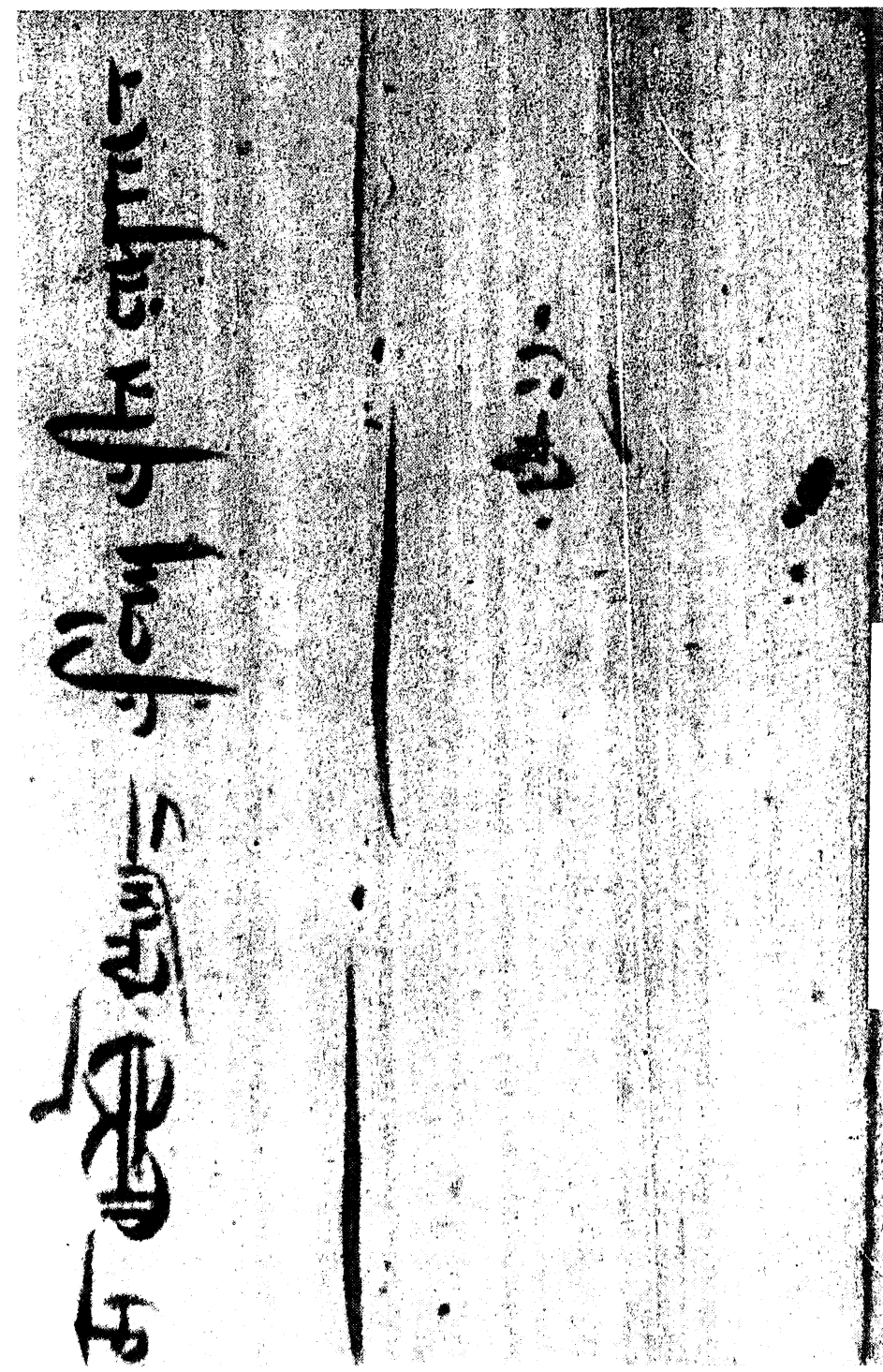

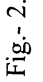




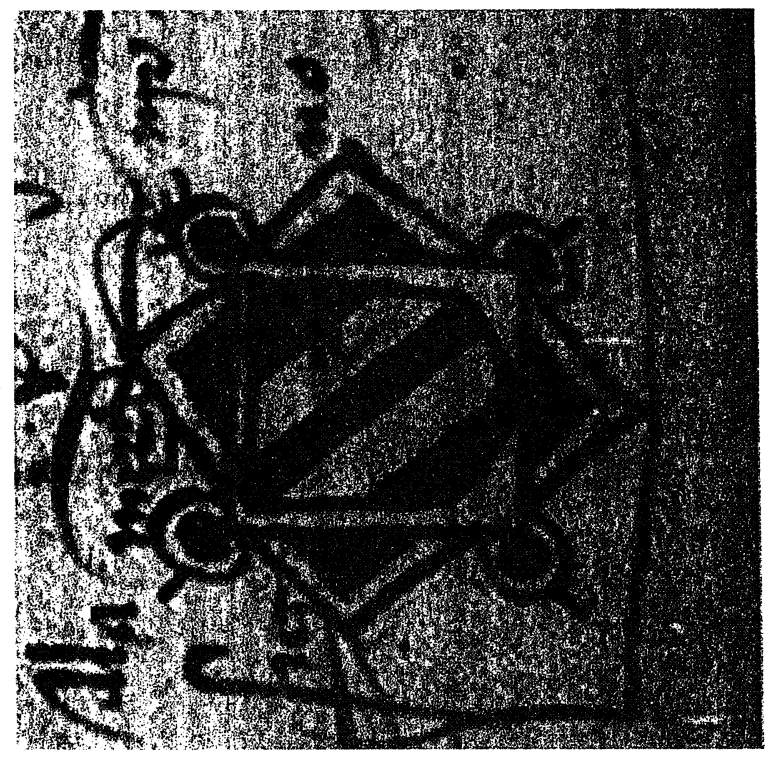

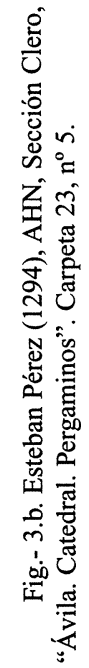

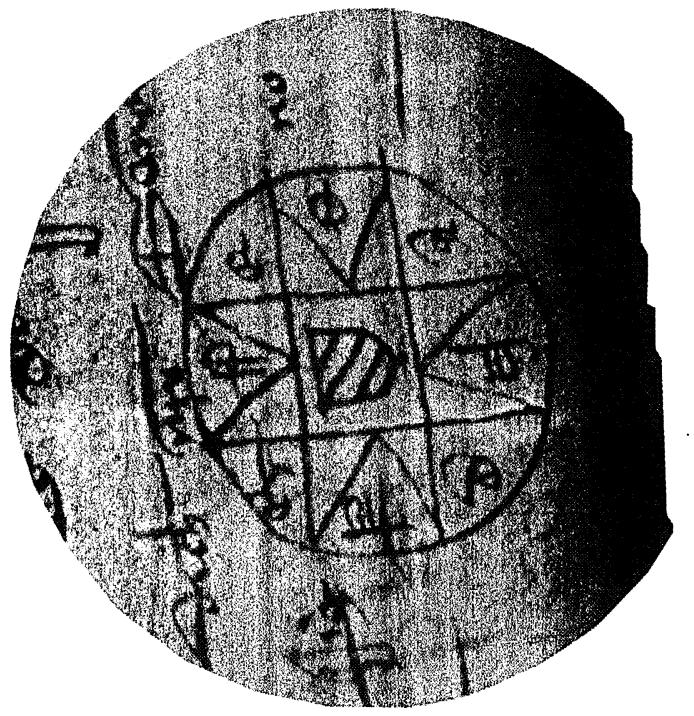

בे 

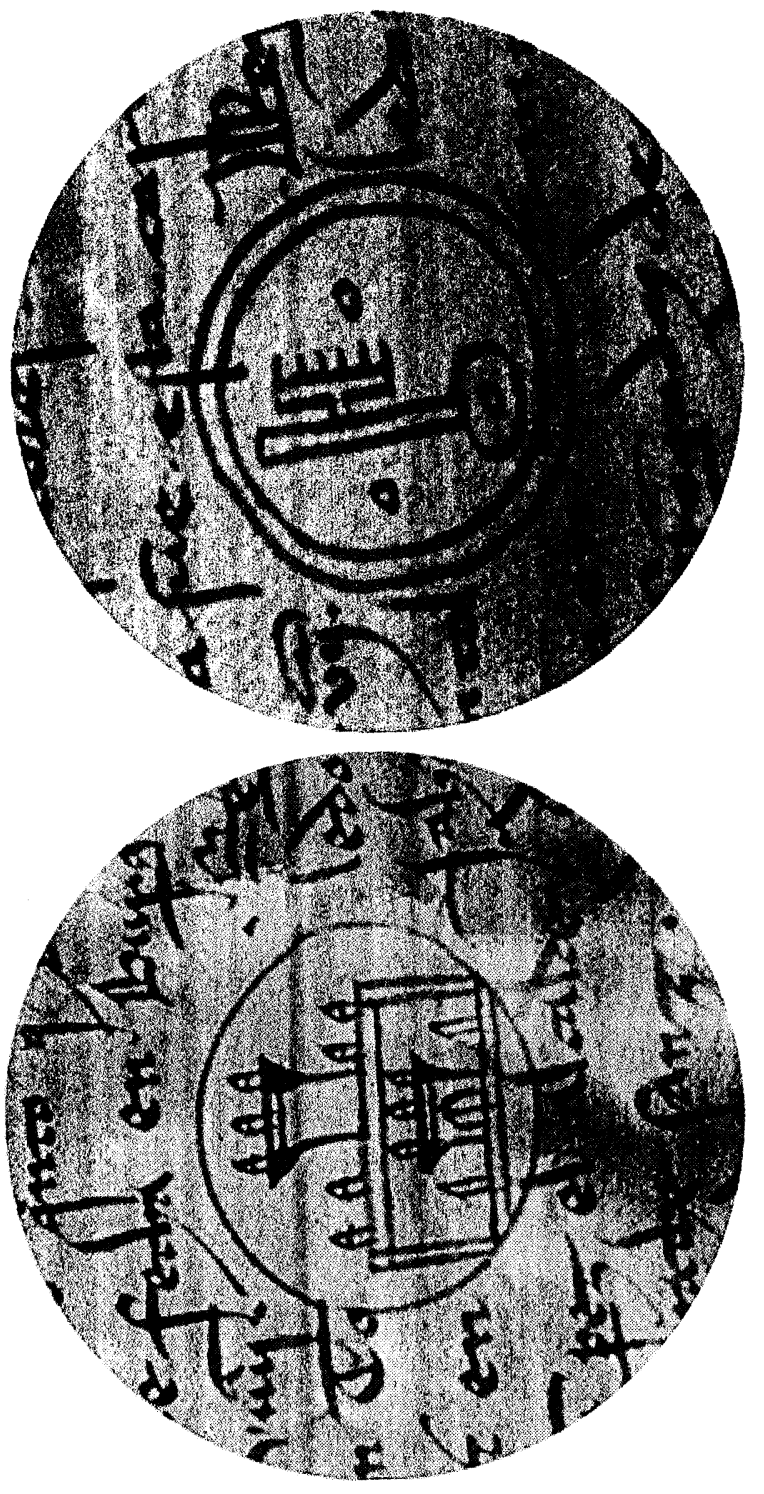

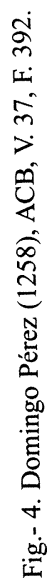



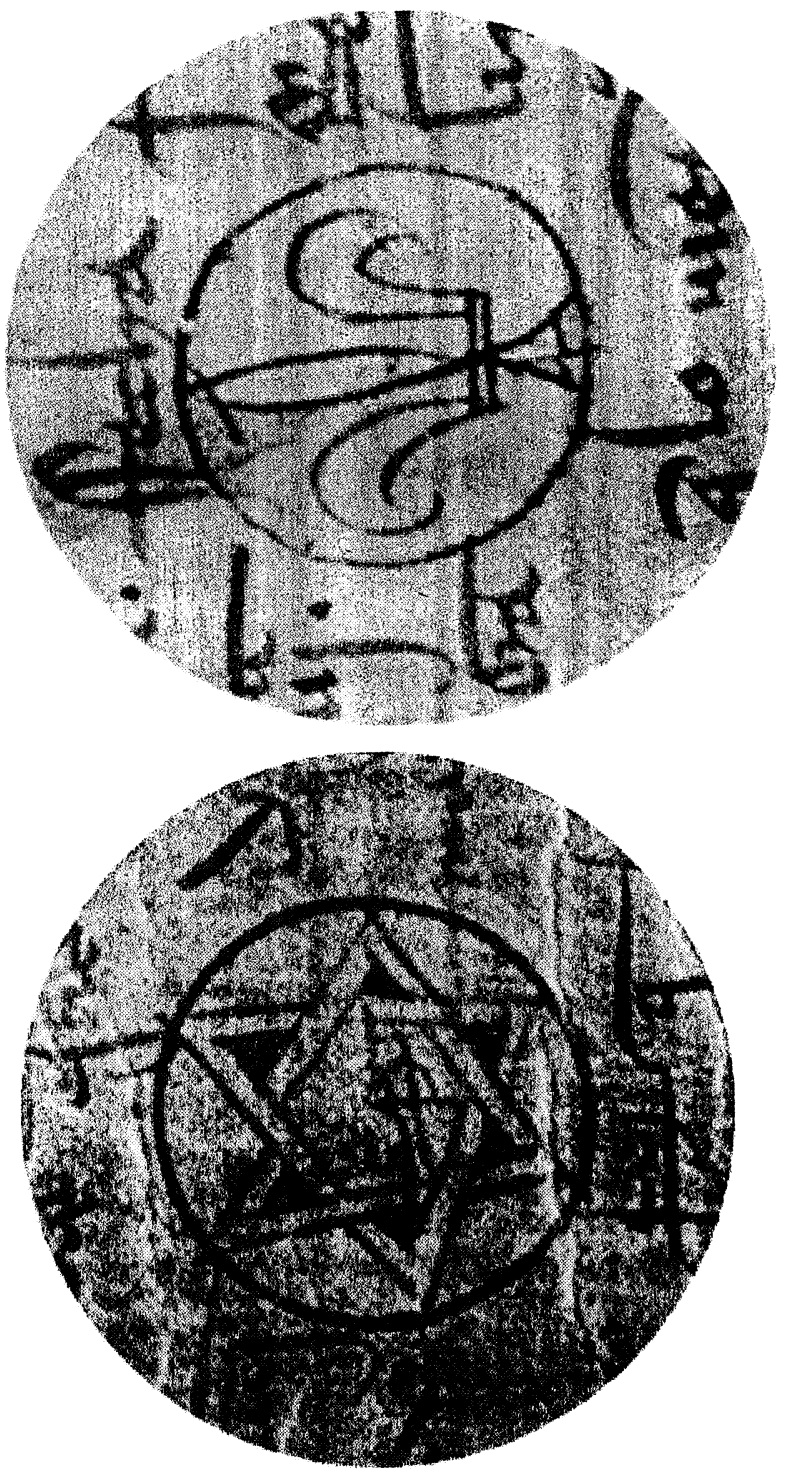

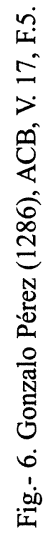

